http://dx.doi.org/10.11646/zootaxa.3681.3.1

http://zoobank.org/urn:lsid:zoobank.org:pub:0473676C-4B88-4919-A5AD-F5612F08FBBE

\title{
Genera of fungivorous Phlaeothripinae (Thysanoptera) from dead branches and leaf-litter in Australia
}

\author{
LAURENCE A. MOUND ${ }^{1}$, LI-HONG DANG ${ }^{2} \&$ DESLEY J. TREE ${ }^{3}$ \\ ${ }^{1}$ CSIRO Ecosystem Sciences, PO Box 1700, Canberra, ACT 2601.E-mail: laurence.mound@csiro.au \\ ${ }^{2}$ Key Laboratory of Zoological Systematics and Evolution, Institute of Zoology, Chinese Academy of Sciences, Beijing, China \\ ${ }^{3}$ Queensland Primary Industries Insect Collection (QDPC), Department of Agriculture, Fisheries and Forestry, Queensland, Brisbane, \\ Qld, 4001
}

\begin{abstract}
An illustrated key is provided for the identification of 39 genera of Thysanoptera-Phlaeothripinae with species that live in association with dead branches and leaf-litter in Australia and are considered to be fungus-feeding. Seven of these genera are not previously recorded from this continent, including un-named species of Deplorothrips, Malacothrips, Mystrothrips, Preeriella and Tylothrips, together with Azaleothrips lepidus Okajima and Terthrothrips ananthakrishnani Kudo. A brief generic diagnosis is provided for each genus, together with comments on systematic problems and numbers of species.
\end{abstract}

Key words: fungus-feeding, genera, identification key, thrips, Australia

\section{Introduction}

Among the 14 recognised families of extant and fossil Thysanoptera (Mound 2011), involving 6050 species in 830 genera, the Phlaeothripidae is by far the largest, with 3520 species in 460 genera (ThripsWiki 2013). However, in this family recognition and definition of genera are exceptionally difficult for three reasons. Firstly, many of the taxa were described from slide-mounted specimens that are technically of low quality, with character states distorted or not visible (see Mound 2008). Moreover, many authors of thrips taxa have never had access to any extensive reference collection of well-mounted specimens, from which to make deductions concerning patterns of structural and colour variation within and among species. As a result of these two factors, many species have been described from single, damaged, individuals, and with limited attempt to recognise their systematic relationships. Problems inherent in the biology of Phlaeothripidae are perhaps even more important. Species in this family are often polymorphic, with winged and wingless individuals, strong sexual dimorphism, and remarkable patterns of allometry. Large and small individuals even of the same sex can be very different in appearance (Mound 2005; Eow et al. 2011; Mound \& Tree 2011; Tree \& Walter 2012). These patterns of variation create not only problems in recognising species, but also serious difficulties in defining genera. This is particularly important with some longestablished genera that have continued to be poorly defined but have come to include a diversity of species. In avoiding adding further species to such poorly defined genera, many authors erect new monotypic genera, such that currently $45 \%$ of the 375 genera of Phlaeothripinae include only a single species. A continuing serious impediment to studies on Phlaeothripinae in all countries is the lack of identification keys to genera. The available keys to genera from Europe (Priesner 1964), North America (Stannard 1957, 1968), and China (Han 1997) all involve nomenclature that is now out of date, although more recent keys are available to genera of the Neotropics (Mound \& Marullo 1996), Japan (Okajima 2006), and Iran (Minaei 2013). 


\section{Systematics of Phlaeothripidae}

Two subfamilies are recognised within the Phlaeothripidae, and a morphology-based classification of the smaller subfamily, Idolothripinae, was provided by Mound \& Palmer (1983). Worldwide, that group comprises 720 species in about 85 genera, and these thrips are presumed all to feed by ingesting fungal spores. In contrast, systematic relationships among the 2800 species in 375 genera of Phlaeothripinae remain largely unrecognised. A system of classification proposed by Priesner (1961) is clearly not phylogenetic, and the three "lineages" proposed by Mound and Marullo (1996), derived largely from Stannard (1957), are not clearly defined. One of these three is now recognised as the tribe Haplothripini, and comprises species in which the fore wing is constricted medially, the prosternal basantral sclerites are present, and a maxillary bridge is present in the head (Mound \& Minaei 2007). The "Liothrips-lineage" of leaf-feeding species is also reasonably well delimited, the species having parallel-sided fore wings, no prosternal basantra, and antennal segments III and IV with one and three sensoria respectively. In contrast, the fungus-feeding species that comprise the "Phlaeothrips-lineage" are highly diverse, many species exhibit complex structural polymorphisms, and phylogenetic relationships amongst the genera will require extensive further study (Buckman et al. 2013).

\section{Australian Phlaeothripidae}

In Australia, there have been extensive studies on this family in recent years, but no identification key exists to the 122 Phlaeothripidae genera listed from this continent (Mound 2013). The subfamily Idolothripinae in Australia was reviewed by Mound (1974), together with a full identification key to genera and species. However, the nomenclature in that study is now out-of-date, although the 23 recorded genera can be identified through a webbased key to the world genera of this sub-family (Mound et al. 2013). In contrast, no identification system is available that treats all of the 99 genera of Phlaeothripinae known from Australia. A few keys are available to some groups within this subfamily: to the 11 genera of the Haplothripini (Mound \& Minaei 2007), to the 30 genera associated with Acacia trees (Crespi et al. 2004), and to the lesser numbers associated with Casuarina species (Mound 1970; Mound \& Crespi 1992) and Geijera species (Mound 1971). The purpose of the present study is to provide an identification key to a further 39 genera of Phlaeothripinae known from Australia. These are the genera that include species associated with dead plants, apparently feeding on fungal hyphae. Most of these genera are well characterised, but each of the final five genera in the key is more problematic. The species of Hoplothrips and Hoplandrothrips are now considered to be far more closely related to each other than was indicated by Priesner (1961) who placed these two genera in different major groups. Deplorothrips species share character states that occur in species of both of these two genera, and many of the species placed in Adraneothrips and Psalidothrips could equally well be considered as small species of Hoplandrothrips. The generic classification thus remains unsatisfactory. All of these genera are represented in the Australian National Insect Collection, Canberra (ANIC), and included here are seven genera not previously recorded from this continent: Azaleothrips, Deplorothrips, Malacothrips, Mystrothrips, Preeriella, Terthrothrips, Tylothrips.

A full checklist of the genera and species of Thysanoptera recorded from Australia is web-available (Mound 2013), and full nomenclatural details of all taxa mentioned here are also accessible through the web (ThripsWiki 2013).

\section{Key to Genera}

1. Compound eyes holoptic, surrounding ocellar region (Fig. 27); mouth cone extending across prosternum [body black, eyes red, abdomen with white markings laterally $] \ldots \ldots \ldots \ldots \ldots \ldots \ldots \ldots \ldots \ldots \ldots \ldots \ldots \ldots \ldots \ldots \ldots \ldots$ Macrophthalms Compound eyes smaller, if surrounding ocellar region, then mouth cone short $\ldots \ldots \ldots \ldots \ldots \ldots \ldots \ldots \ldots \ldots \ldots$

2. Antennal segment III 0.5 as long as IV, these segments closely joined (Fig. 12); body flattened laterally, not dorso-ventrally

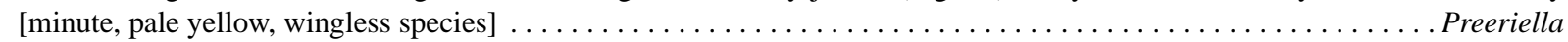
Antennal segment III rarely much smaller than IV; body dorso-ventrally flattened. $\ldots \ldots \ldots \ldots \ldots \ldots \ldots \ldots \ldots$

3. Antennal segment II with circular sensorium on median or basal half of segment (Figs 11, 15); abdominal tergite II strongly

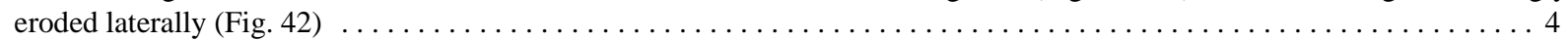
Antennal segment II with circular sensorium on apical half of segment (Figs 8, 21); abdominal tergite II rarely eroded laterally

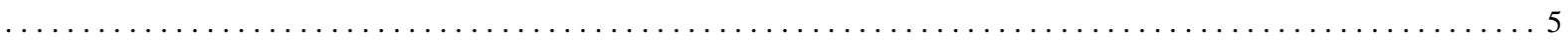




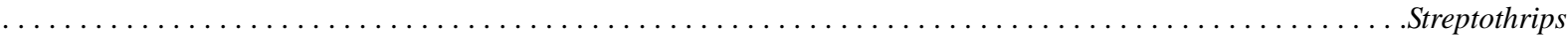
Antennal segment IV longer than wide, with 3 prominent sensoria (Fig. 11); female sternite VIII without row of stout setae ..

5.

. Maxillary stylets variable in length, at least partly anterior to postoccipital ridge $\ldots \ldots \ldots \ldots \ldots \ldots \ldots \ldots \ldots \ldots$

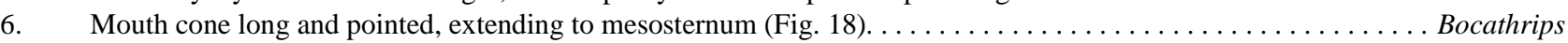

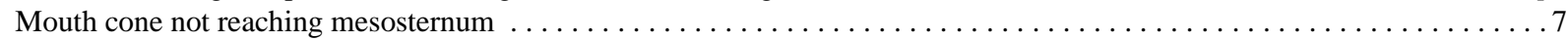

7. Head wider than long, cheeks without strong setae; mouth cone broadly rounded; body very small, commonly yellowish;

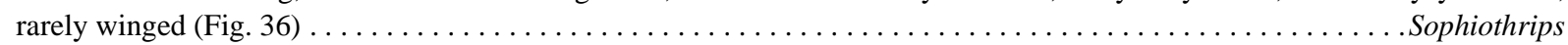
Head at least as long as wide, usually longer, cheeks usually with one pair of prominent setae (Fig. 16); mouth cone pointed;

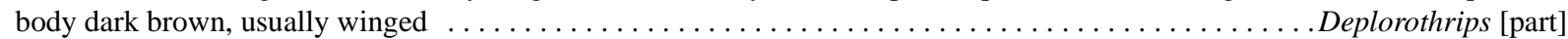

8. Tergite VIII with 2 (rarely 1) pairs of weakly sigmoid wing-retaining setae (Fig. 33)............... Solomonthrips

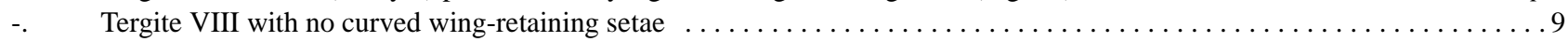

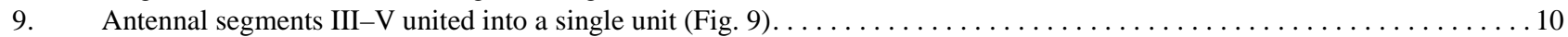

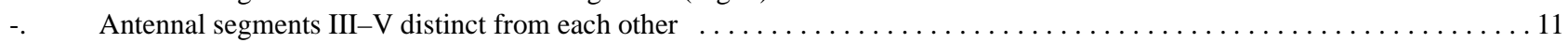

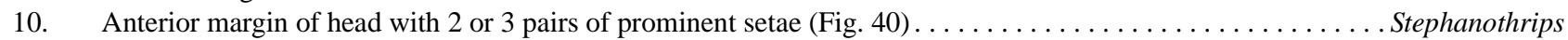

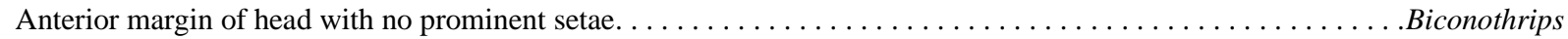

11. Abdominal segment IX long, twice as long as wide, and 3 times as long as VIII (Figs 19, 32) $\ldots \ldots \ldots \ldots \ldots \ldots \ldots \ldots$

-. Abdominal segment IX not elongate, rarely longer than wide, and less than twice as long as VIII $\ldots \ldots \ldots \ldots \ldots \ldots$

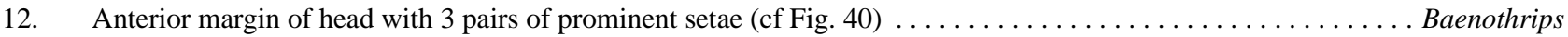

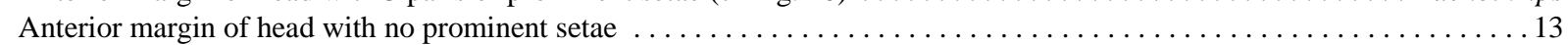

13. Head projecting in front of eyes, projection about as long as dorsal eye length (Fig. 22); eyes equally developed dorsally and

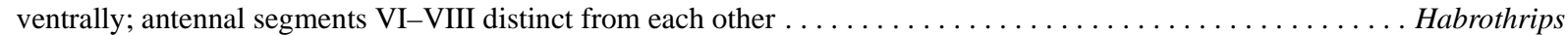
Head not projecting in front of eyes but overhanging basal antennal segments (Fig. 31); eye present dorsally only; antennal segments VI-VIII closely joined but with sutures complete $\ldots \ldots \ldots \ldots \ldots \ldots \ldots \ldots \ldots \ldots \ldots \ldots \ldots$ Octurothrips

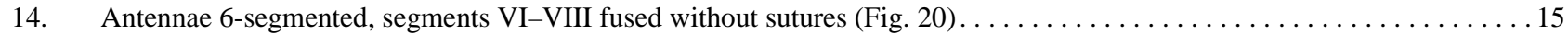
Antennae 7- or 8-segmented, at least segment VI distinct from VII $\ldots \ldots \ldots \ldots \ldots \ldots \ldots \ldots \ldots \ldots \ldots \ldots \ldots$

15. Maxillary stylets retracted to compound eyes and close together medially in head; mesopraesternum divided into two well-sep-

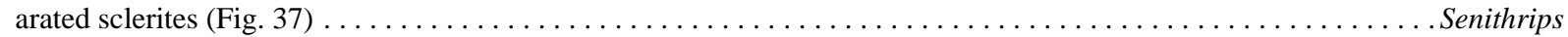
Maxillary stylets wide apart in head (Fig. 2); mesopraesternum not divided . . . . . . . . . . . . . . . . Adurothrips

16. Antennal segment III with more than 6 very stout sensoria with rounded apices (Fig. 21); fore femora with tubercle on inner

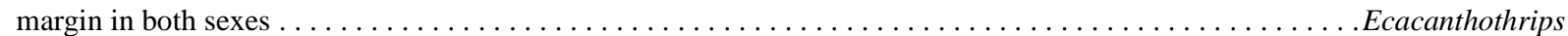
Antennal segment III with no more than 4 sensoria, slender with pointed apices; inner margin of fore femora usually without a

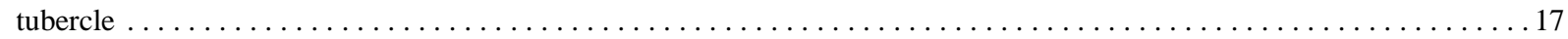

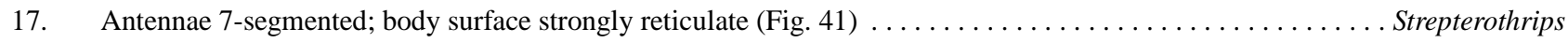
Antennae 8-segmented, but VII+VIII sometimes closely joined; body surface variously sculptured; if with only 7 antennal seg-

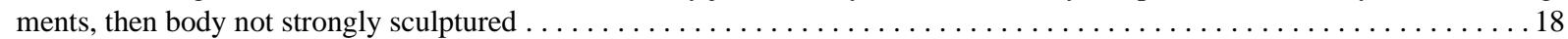

18. Maxillary stylets long, retracted to eyes and close together medially in head (Figs 6, 24, 28); antennal segments VII-VIII

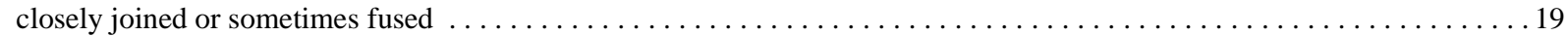
Maxillary stylets usually short and far apart, if long, then antennal segment VIII clearly distinct from VII $\ldots \ldots \ldots \ldots .21$

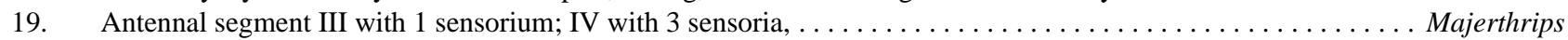
Antennal segment III with either 2 or 3 sensoria; IV with 4 sensoria, rarely with $3 \ldots \ldots \ldots \ldots \ldots \ldots \ldots \ldots \ldots$

20. Antennal segment III with 3 sensoria; maxillary stylets width usually more than 4 microns (Fig. 25) . . . . . . . . . Holothrips Antennal segment III with 2 sensoria; maxillary stylets slender, scarcely more than 3 microns (Fig. 6). . . . . . Asemothrips

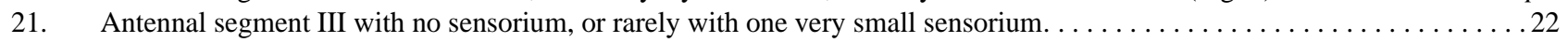

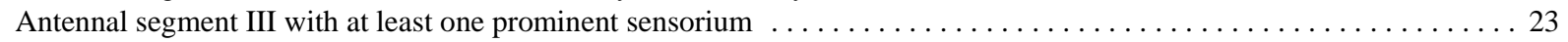

22. Cheeks constricted behind spherical compound eyes (Figs 4, 5); body surface with very little sculpture; prosternal basantra

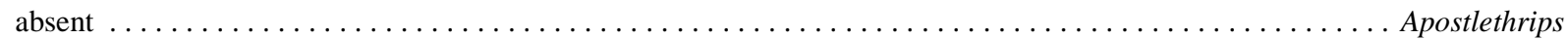
Cheeks prolonged laterally around posterolateral margin of elongate eyes (Fig. 26); body surface with complex reticulate sculpture; prosternal basantra present $\ldots \ldots \ldots \ldots \ldots \ldots \ldots \ldots \ldots \ldots \ldots \ldots \ldots \ldots \ldots \ldots \ldots \ldots \ldots \ldots$

23. Pronotum with 4 pairs only of long capitate setae, anteromarginal pair long but anteroangular pair minute or absent (Fig. 47) .

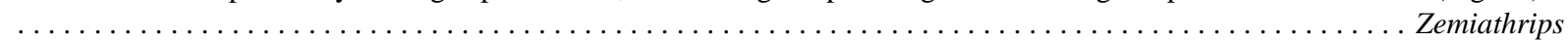

Pronotal chaetotaxy different, anteroangular setae rarely shorter than anteromarginal setae . . . . . . . . . . . . 24

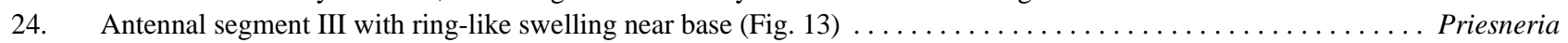

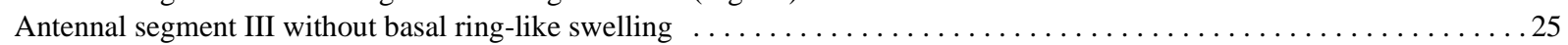

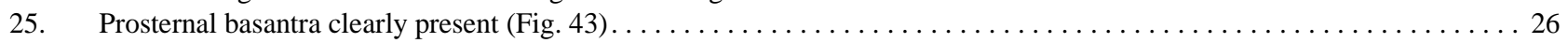

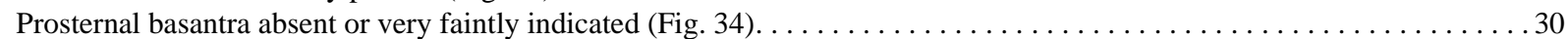

26. Antennal segment III with 1 sensorium, IV with 2 sensoria; mouth cone very long, either extending posteriorly between fore

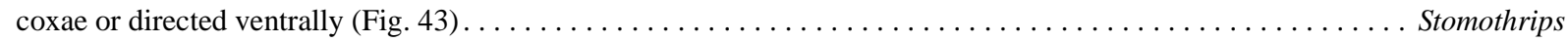
Antennal segment III with 2 or 3 sensoria, IV with 3 or 4 ; mouth cone less elongate $\ldots \ldots \ldots \ldots \ldots \ldots \ldots \ldots \ldots \ldots$

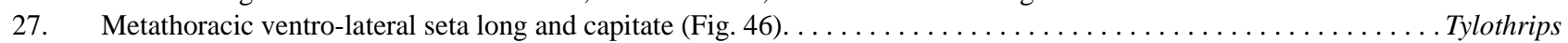

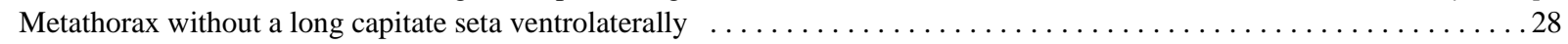


28. Antennal segment III with 2 sensoria, IV with 2 or 3 ; fore tibia inner margin often with row of small tubercles (Fig. 45) .....

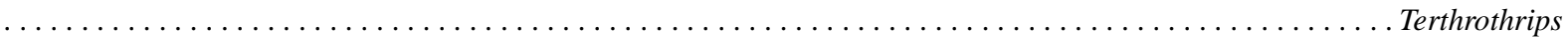

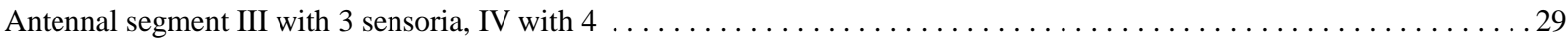

29. Maxillary stylets less than one-fifth of head width apart, maxillary bridge absent (Fig. 29); antennal segment VIII with basal

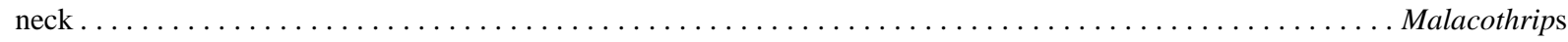
Maxillary stylets at least one third of head width apart, maxillary bridge present and arched (Fig. 44); antennal segment VIII

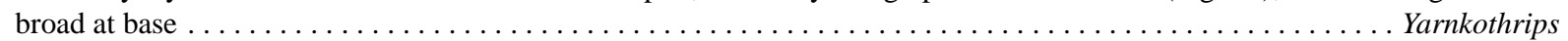

30. Pronotal major setae short with broadly expanded apices, body surface reticulate with many sculpture lines inside each reticle

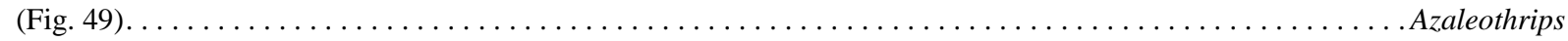
Pronotal major setae much longer than width of apices; body without complex reticulation $\ldots \ldots \ldots \ldots \ldots \ldots \ldots$

31. Maxillary stylets unusually stout, at least 5 microns in diameter along their full length (Fig. 3)...........Apelaunothrips

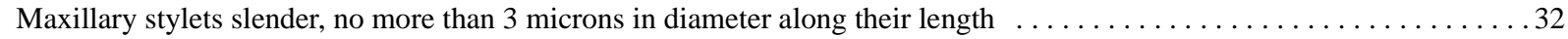

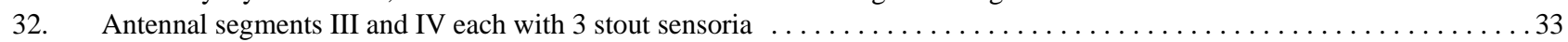

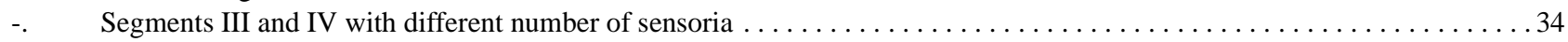

33. Antennal segment VIII sharply constricted to basal neck (Fig. 14); maxillary stylets retracted anterior to posterior margin of eyes and close together along full length of head (Fig. 38); brownish yellow species. . . . . . . . . . . . Pygmaeothrips Antennal segment VIII not sharply constricted at base; maxillary stylets retracted to postocular setae, almost one fifth of head

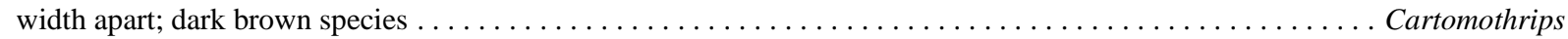

34. Maxillary stylets retracted anterior to posterior margin of eyes, close together medially for full length of head (Fig. 24); antennal segment III with 1 sensorium, IV with 2 or 3 sensoria; segment VIII not constricted at base . . . . . . . . . . Horistothrips Maxillary stylets not retracted anterior to postocular setae, usually further apart (Figs 3, 30); if retracted to posterior margin of eyes and close together medially, antennal segment IV usually with 4 sensoria $\ldots \ldots \ldots \ldots \ldots \ldots \ldots \ldots \ldots \ldots \ldots$

35. Head, thorax and antennal segments strongly reticulate, major setae with broadly expanded apices (Fig. 30); head with cheeks

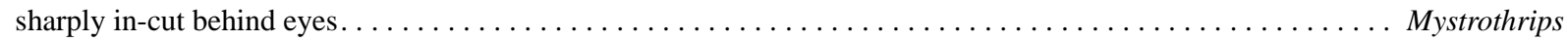
At least antennal segments not strongly reticulate, head not in-cut behind eyes; major setae apices varied . . . . . . . . 36

36. Metathoracic sternopleural sutures absent; fore tarsal tooth usually not developed; pronotum with five pairs of major setae with capitate apices (Fig. 1); body and antennal segments III-V frequently sharply bicoloured............... Adraneothrips Metathoracic sternopleural sutures present (Fig. 34); fore tarsal tooth present in males, usually present in females; other char-

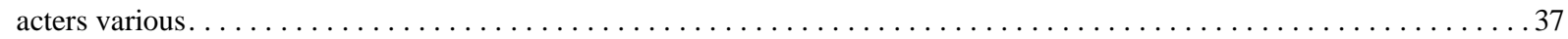

37. Maxillary stylets short, V-shaped, scarcely retracted anterior to postoccipital ridge, or about one third of head width apart and

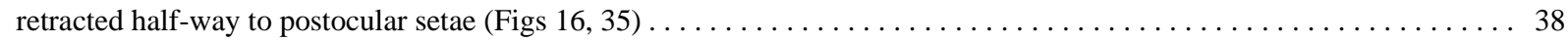
Maxillary stylets deeply retracted into head, close together medially (Figs 23,48$) \ldots \ldots \ldots \ldots \ldots \ldots \ldots$

38. Body yellow to light brown, head with no stout setae on cheeks; pronotum anterior margin usually without any prominent setae

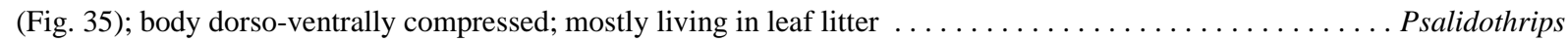
Body dark brown, head with at least one pair of small but stout cheek setae (Fig. 16); pronotal anteroangular setae well developed; frequently sexually dimorphic; mostly living on dead wood $\ldots \ldots \ldots \ldots \ldots \ldots \ldots \ldots \ldots$ Deplorothrips [part]

39. Major setae usually pointed or narrowly blunt at apex (Fig. 23); wing-reduction common, fore wings parallel sided if devel-

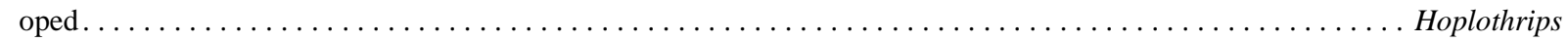
Major setae usually expanded at apex (Fig. 48); usually macropterous, fore wings usually weakly constricted medially ......

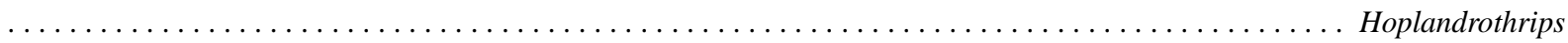

\section{Adraneothrips Hood}

Most of the described species in this genus are Neotropical, and a key to 32 of the 59 listed species was provided by Mound and Marullo (1996). However, Stigmothrips Ananthakrishnan with 13 described species from the Asian tropics will be treated as a synonym in a manuscript currently in preparation. Adraneothrips braccatus is the only species currently listed from Australia, but at least three further species are represented in ANIC (Fig. 1). These thrips have all been found in northern Australia from dead grasses and dead leaves. Despite the absence of the metathoracic sternopleural sutures, this genus is possibly related to Hoplandrothrips, although the species exhibit little sexual polymorphism.

Diagnosis. Head with cheeks slightly constricted behind large eyes; postocular setae usually arise behind inner margin of eyes; stylets usually about $1 / 3$ of head width apart, retracted to postocular setae; antennae 8 -segmented, III with 2 or 3 sensoria, IV with 3 or 4 ; pronotum with 5 pairs of capitate setae, notopleural sutures incomplete or weakly complete; basantra absent, mesopraesternum transverse; sternopleural sutures absent; fore tarsal tooth usually not developed; fore wings weakly constricted medially, with or without duplicated cilia; pelta slightly longer than wide and usually bell-shaped; tergites II-VII with 2 pairs of wing-retaining setae, each posterior pair usually thicker than anterior pair; tergite IX with accessory setae between S1 and S2 almost as long as S1; tube with straight sides, slightly shorter than head; male sternite VIII with or without pore plate. 

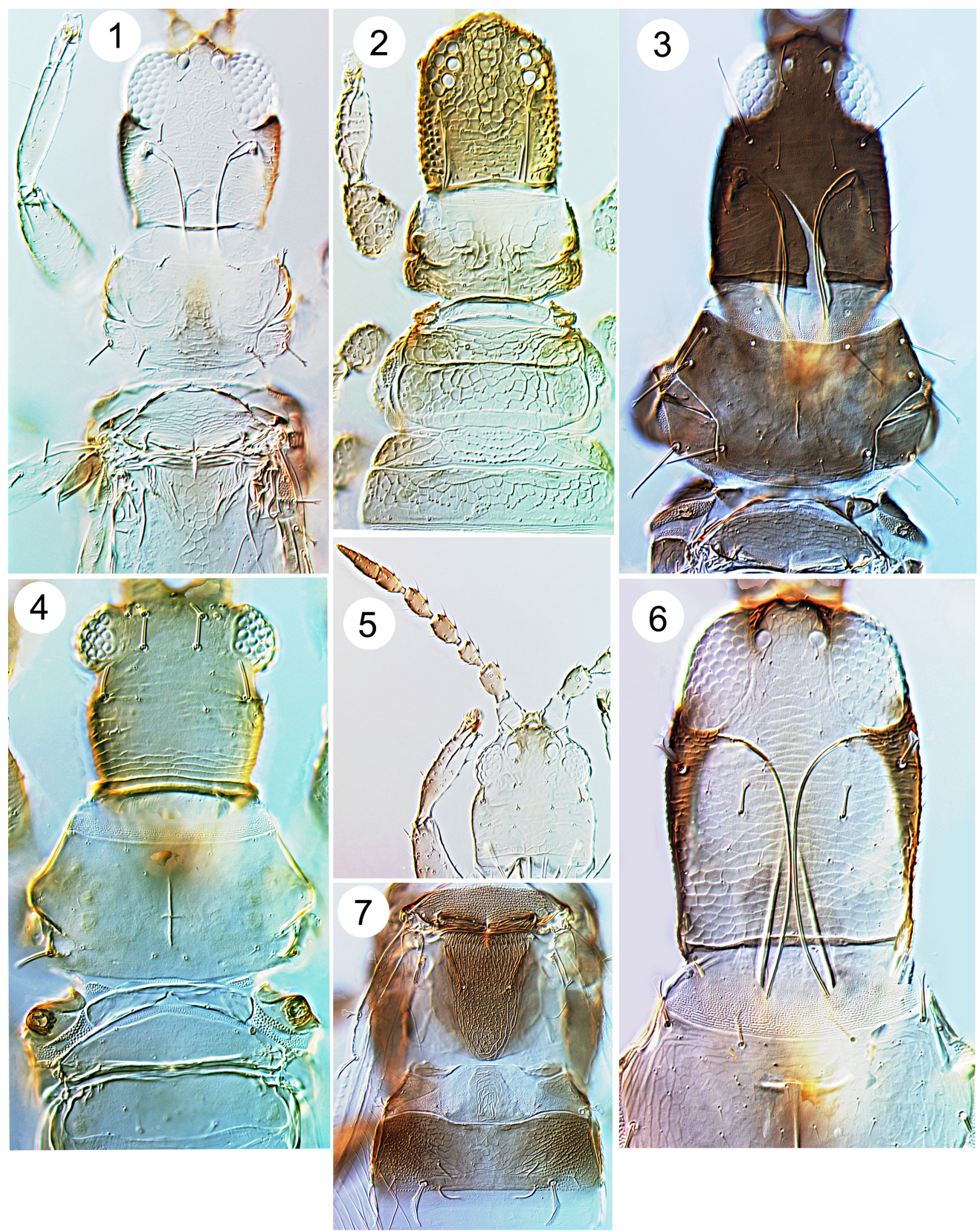

FIGURES 1-7. Phlaeothripinae genera. (1) Adraneothrips sp.; (2) Adurothrips atopus; (3) Apelaunothrips tasmani; (4) Apostlethrips pygus; (5) Apostlethrips apostus; (6) Asemothrips picturatus; (7) Azaleothrips lepidus, metanotum. 


\section{Adurothrips Mound}

The only known species in this Australian genus, A. atopus, is widespread in leaf litter in eastern Australia (Fig. 2). The genus is considered related to the long-tubed, Urothripine genera such as Baenothrips and Stephanothrips, despite the tube and anal setae being short.

Diagnosis. Apterous, body small; head reticulate dorsally, with tuberculate cheeks, stylets wide apart; compound eyes with less than 15 ommatidia; antennae 6-segmented, II asymmetric, III with 1 sensorium, IV with 2 sensoria; pronotum with no long setae, no notopleural sutures; basantra small, placed laterally, mesopraesternum degenerate; no sternopleural sutures; fore tarsi without tooth; pelta transverse, tripartite; tergite IX scarcely longer than VIII; tube shorter than head, anal setae shorter than tube; male sternite VIII without pore plate.

\section{Apelaunothrips Priesner}

Okajima (1979) provided a key to 19 of the 35 species now listed in this genus. These species live in leaf litter and on dead twigs. One bicoloured species, A. tasmani, was described from northern Queensland and is also known from near Darwin in Northern Territory (Fig. 3), but a second species, with the head and abdomen largely yellow, has been collected at Cape Tribulation.

Diagnosis. Head often longer than wide, cheeks weakly rounded, without stout setae, slightly incut behind large eyes; postocular setae usually long, capitate; maxillary stylets long, close together medially, broader than typical Phlaeothripinae; antennae 8-segmented, III with 3 (or 2) sensoria, IV with 4 (or 3) sensoria; pronotum usually with 5 pairs of capitate setae, notopleural sutures complete ; basantra absent; mesopraesternum transverse; no sternopleural sutures; fore tarsi usually without tooth in both sexes; fore wings, if present, weakly constricted medially, with duplicated cilia; pelta triangular or bell-shaped; tergites II-VII each with 2 pairs of wing-retaining setae in macropterae; tube shorter than head, anal setae usually shorter than tube; male sternite VIII without pore plate.

\section{Apostlethrips Mound}

Known only from Australia, this genus comprises only two species, A. apostus and A. pygus (Figs 4, 5). Both of these were collected in northwest Australia from the base of Triodia grasses.

Diagnosis. Head longer than wide, prolonged in front of large eyes, cheeks constricted behind eyes, vertex with almost no sculpture; ocellar and postocular setae stout, weakly capitate; maxillary stylets wide apart, low in head; antennae 8-segmented, III with no sensorium, IV with 2 sensoria, VI-VIII distinct but broadly connected; pronotum without sculpture, only 2 pairs of major setae, notopleural sutures incomplete; basantra large, with 3-5 pairs of setae; mesopraesternum slender and transverse; no sternopleural sutures; fore tarsi with or without small curved tooth in both sexes; usually micropterous, fore wing when present without duplicated cilia; pelta triangular, without sculpture; tergites II-VII with one or two pairs of stout weakly capitate marginal setae but no wingretaining setae; tube slightly shorter than head, anal setae shorter than width of tube apex; male sternite VIII without pore plate.

\section{Asemothrips Hood}

Of the five species listed in this genus four, A. combustipes, A. fallax, A. finlayi, and A. picturatus, are from Australia, and the fifth is from Sumatra. The Australian species have the maxillary stylets rather broader than is typical of Phlaeothripinae, and this has been interpreted as indicating a relationship to Holothrips in a putative Tribe called Docessissophothripini (Mound \& Palmer 1983). However, the females of none of the Australian species have reticulate areas on the sternites similar to those found commonly in Holothrips species. Antennal segments V-VI have strikingly asymmetric apices (Fig. 8), a characteristic shared with the species in the related genus, Majerthrips. The type species of the genus, A. picturatus (Fig. 6), has been taken in association with 
Lophostemon at three different sites across northern Australia, Bundaberg, Katherine and Badu Is. However, A. fallax and A. finlayi are both known from very few specimens, and are possibly associated with Eucalyptus in eastern Australia.

Diagnosis. Head longer than wide, cheeks weakly convex; postocular setae short and capitate, or minute; stylets retracted to eyes, close together medially; antennae 8-segmented, III with 2 sensoria, IV with 4 sensoria; pronotum with 2 or 5 pairs of capitate setae, notopleural sutures complete; basantra absent; mesopraesternum transverse; sternopleural sutures present; metanotum with at least 5 pairs of minor setae; fore tarsal tooth well developed in both sexes; fore wings parallel-sided, without duplicated cilia; pelta hat-shaped; tergites II-VI each with 2 pairs of wing-retaining setae, reduced and straight on VII; tube shorter than head, anal setae a little shorter than tube; male sternites II-V (or VII) with worm-like reticulate areas, VIII without pore plate.

\section{Azaleothrips Ananthakrishnan}

Ten species, between India and Japan, are currently placed in this genus, but no species has previously been recorded or described from Australia. However, one female of A. lepidus Okajima, a species known only from Thailand, has been studied (Figs 7, 49) from Cobourg Peninsula, Northern Territory (Mound \& Dang, in press). Moreover, in ANIC there are two females of an undescribed species from the Coorong of South Australia.

Diagnosis. Body with complex reticulation; head about as long as wide; postocular setae short, capitate, behind inner margins of eyes or absent; stylets long, retracted to eyes, close together medially; antennae 8segmented, VIII more or less fused to VII; segment III with 3 sensoria, IV with 4; pronotum with 5 pairs of capitate setae, notopleural sutures complete; basantra absent; mesopraesternum transverse, slender; sternopleural sutures long; female with small fore tarsal tooth; fore wings weakly constricted medially, with duplicated cilia; pelta broadly bell-shaped; tergites II-VII each with 2 pairs of wing-retaining setae, each posterior pair larger than anterior pair, tergal major setae broadly capitate; tube shorter than head, anal setae as long as tube; male sternite VIII with a large pore plate.

\section{Baenothrips Crawford}

Of the 11 species worldwide listed in this genus, two are described from Australia. B. caenosus is from eastern Australia, and B. moundi is widespread from Tasmania to Cape Tribulation, but there are several undescribed species from eastern Australia in ANIC. The remaining species in the genus are described from various countries in tropical areas, and all members of the genus live in leaf litter or on dead twigs.

Diagnosis. Body tuberculate-reticulate; head anterior margin with 3 pairs of prominent setae, compound eyes reduced to 10-15 facets; stylets retracted to eyes, 1/3 of head width apart; antennae 8-segmented, III with no sensorium, IV with 2 sensoria; pronotum with only epimeral setae well-developed, notopleural sutures reduced; basantra reduced to 2 small lateral triangles; mesopraesternum slender, transverse; metathoracic epimera enlarged and tuberculate, no sternopleural sutures; fore tarsi without tooth; fore wings, if present, narrow, no duplicated cilia; pelta transverse; tergites II-VII each with 2 pairs of broad wing-retaining setae in macropterae; tergite IX three times as long as VIII; tube long and slender with apex slightly widened; anal setae more than twice as long as tube; male sternite VIII without pore plate.

\section{Biconothrips Stannard}

This Urothripine genus is closely related to Urothrips from Africa, but the only described species, B. reedi, is known only from various sites in eastern Australia (Fig. 9). However, Mound (1972a) indicated that there is considerable variation between populations, and this may reflect a series of localised species.

Diagnosis. Apterous, body tuberculate-reticulate; head anterior margin projecting over bases of antennae, without prominent setae; eyes with about 8 ommatidia; stylets retracted almost to eyes, about $1 / 3$ of head width apart; antennae 5-segmented, morphological segments III-V fused, VII-VIII fused to form slender segment; pronotum without prominent setae, or with epimeral setae well-developed, notopleural sutures reduced; basantra 
absent; mesopraesternum absent or very slender; no sternopleural sutures; fore tarsi without tooth; pelta transverse, closely joined to tergite II; tergite IX twice as long as VIII; tube about as long as IX, anal setae more than three times as long as tube; male sternite VIII without pore plate.

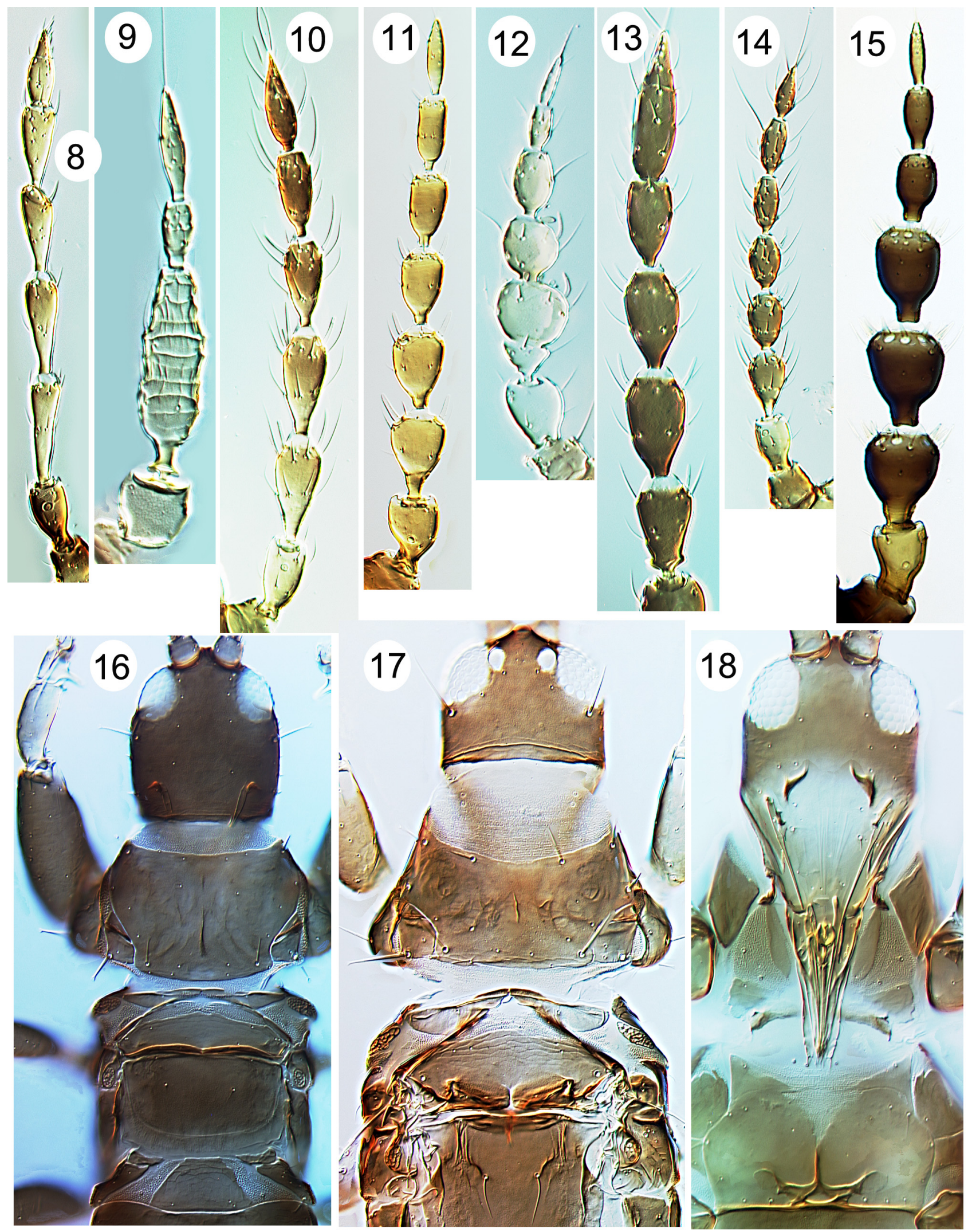

FIGURES 8-18. Phlaeothripinae genera. 8-15 antennae: (8) Asemothrips picturatus; (9) Biconothrips reedi; (10) Holothrips oceanicus; (11) Plectrothrips australis; (12) Preeriella sp.; (13) Priesneria peronis; (14) Pygmaeothrips angusticeps; (15) Streptothrips tribulatius. (16) Deplorothrips sp.; (17-18) Bocathrips okajimai. 


\section{Bocathrips Goldarazena}

This genus is known from a single species, B. okajimai, based on three specimens taken from dead branches near Canberra (Goldarazena 2010). The species is particularly unusual in having the maxillary stylets not retracted anterior to the occipital ridge, despite having a long mouth cone (Figs 17, 18).

Diagnosis. Head dorsally wider than long; postocular setae wide apart, as long as eye length; mouth-cone extending to mesosternum; stylets restricted to mouth cone, V-shaped; antennae 8-segmented, III and IV with 3 and 4 sensoria respectively in macroptera, but 1 and 2 respectively in aptera, VIII slender; pronotum with 5 pairs of major setae, notopleural sutures complete; basantra present; mesopraesternum reduced to two lateral triangles, partly fused to mesoeusternum; no sternopleural sutures; fore tarsal tooth absent in both sexes; fore wings, if present, weakly constricted medially, without duplicated cilia; pelta triangular; tergites II-VII with one pair of wing-retaining setae in macroptera, reduced in aptera; tube with straight sides, as long as head, anal setae longer than tube.

\section{Cartomothrips Stannard}

This genus now includes 12 species, all from Australia or New Zealand, and these seem to breed particularly within the dry fruiting capsules of various Myrtaceae, particularly Eucalyptus and Leptospermum species (Mound \& Walker 2012). However, it remains unclear if these thrips and their larvae feed on fungi or on the old seeds.

Diagnosis. Macropterous, body, legs and antennae brown; head longer than wide, cheeks weakly convex, with few weak setae; postocular setae wide apart far from eyes; maxillary stylets about one fifth of head width apart, retracted almost to eyes; antennae 8-segmented, III and IV each with 3 stout sensoria; pronotum short medially, notopleural sutures complete, anteromarginal setae short; metanotum reticulate. Fore tarsus with prominent tooth; fore wing parallel sided, with about 12 duplicated cilia; prosternal basantra not developed, mesopraesternum reduced to two lateral triangles; metathoracic sternopleural sutures long and curved. Pelta triangular; tergites II-VII each with 2 pairs of wing-retaining setae; tergite IX setae shorter than tube; male sternite VIII with transverse pore plate.

\section{Deplorothrips Mound \& Walker}

Described for a single species from New Zealand, this genus now includes a further eight species from southeast Asia. No species has yet been described from Australia, but there are many specimens representing this genus in ANIC, collected from dead branches at localities widespread across eastern Australia (Fig. 16). The New Zealand species was described as exhibiting remarkable inter-population variation, and species-level taxonomy in the genus remains difficult.

Diagnosis. Head as long as wide or longer, cheeks usually with at least one pair of small stout setae; postocular setae usually developed; stylets V-shaped, retracted scarcely or not at all anterior to occipital ridge; antennae 8segmented, VIII broad at base, often fused with VII, III with 3 sensoria, IV with 4 or rarely 3; pronotum usually with 4 pairs of major setae, anteromarginals usually reduced; notopleural sutures complete; basantra absent; mesopraesternum transverse; sternopleural sutures present; fore tarsal tooth present in both sexes; fore tibia usually with subapical tubercle in male; fore wings, if present, weakly constricted medially, duplicated cilia preent; pelta bell-shaped, or broader; tergites II-VII each with 2 pairs of wing-retaining setae in macroptera; tube shorter than head, anal setae about as long as tube; male sternites II-VII usually with reticulate areas, VIII with pair of pore plates, or one slender one.

\section{Ecacanthothrips Bagnall}

This genus comprises 11 species from southeast Asia, and appears to represent a particular subgroup of Hoplandrothrips with multiple, large, sensoria on the third antennal segment (Fig. 21). These thrips live on dead 
branches, and E. tibialis, a highly variable species widespread in the Old World tropics, has been found in Queensland.

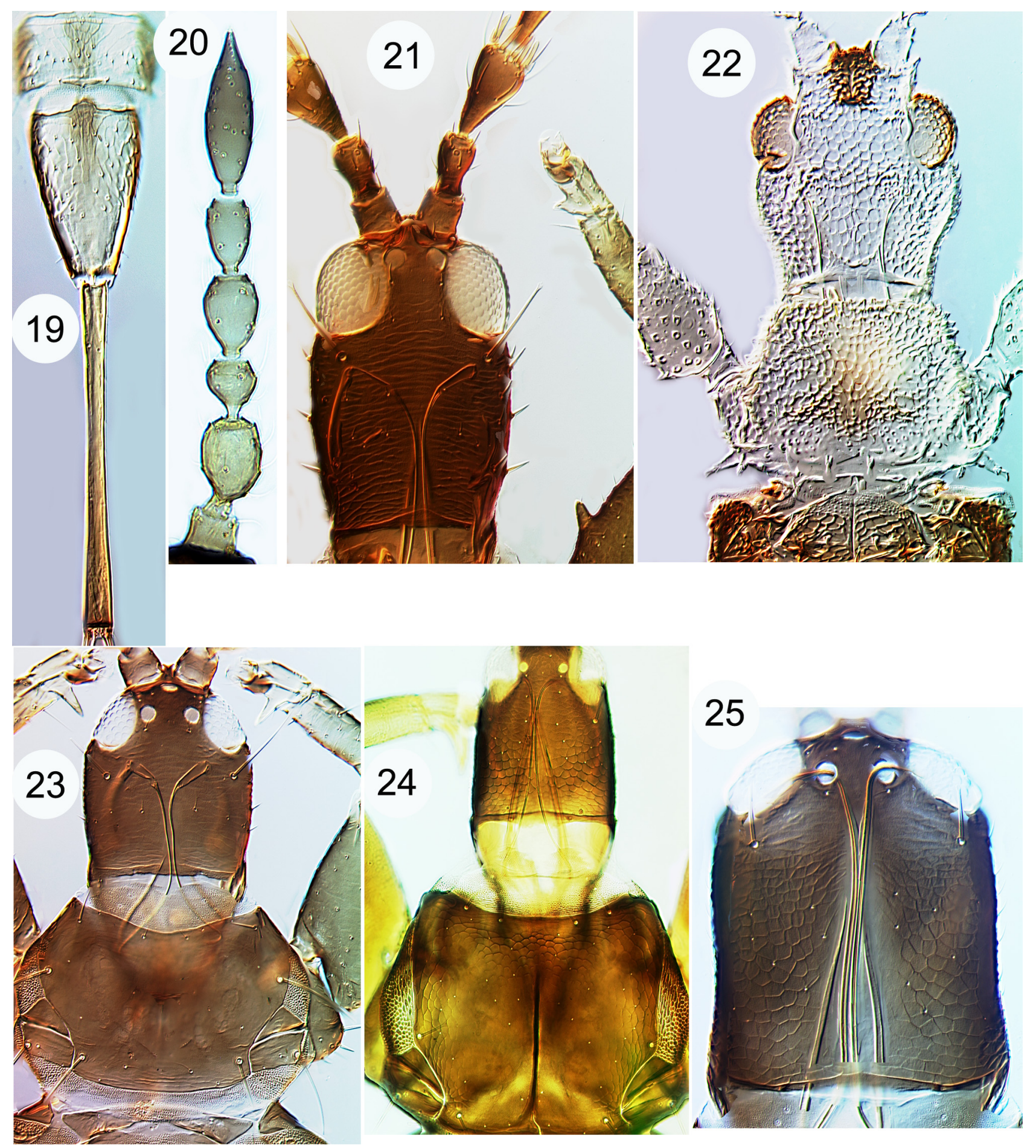

FIGURES 19-24. Phlaeothripinae genera. (19) Baenothrips moundi, tergites IX-X; (20) Senithrips psomus, antenna; (21) Ecacanthothrips tibialis, small male; (22) Habrothrips curious; (23) Hoplothrips orientalis small male; (24) Horistothrips australis; (25) Holothrips oceanicus.

Diagnosis. Head as long as wide or much longer, cheeks usually with stout setae; postocular setae long; stylets long and retracted to eyes, close together medially; antennae 8-segmented, III usually with at least 6 stout sensoria, IV with 4; pronotum usually with 5 pairs of major setae; notopleural sutures complete; basantra absent; mesopraesternum usually eroded medially and divided into three; sternopleural sutures present; fore tarsi present in both sexes, fore femur usually with pair of apical tubercles in male; fore femur sometimes with median tooth at 
inner margin in both sexes; fore wings weakly constricted medially, with duplicated cilia; pelta triangular or bellshaped; tergites II-VII each with 2 pairs of wing-retaining setae, often with several accessory wing-retaining setae; tube shorter than head, anal setae a little shorter than tube; male sternite VIII without pore plates.

\section{Habrothrips Ananthakrishnan}

The only species in this Urothripine genus, $H$. curiosus (Fig. 22), was described from India. It lives in leaf-litter and on dead twigs, and has been studied from southeast Asia as well as northern Australia (Mound 1972a).

Diagnosis. Body tuberculate-reticulate; head with prominent preocular prolongation; maxillary stylets wide apart, retracted to postocular setae; antennae 8-segmented, segment III with 2 sensoria, IV with 4 sensoria; pronotum with only epimeral setae well-developed, no notopleural sutures; basantra absent; mesopraesternum complete, slender; no sternopleural sutures; fore tarsi without tooth; fore wings, if present, narrow, no duplicated cilia; pelta broad; tergites II-VII each with 2 pairs of broad wing-retaining setae in macropterae; tergite IX more than twice as long as VIII; tube slender, about twice as long as head, anal setae more than twice as long as tube; male without pore plates.

\section{Holothrips Karny}

Almost 130 species are listed in this genus, and Okajima (1987) provided a key to 69 species from the Old World. Three species are described from Australia, H. australis, H. oceanicus and H. speciossissimus, but several undescribed species are represented in ANIC that have been taken widely between Tasmania and northern Queensland. The maxillary stylets are distinctly wider than those of typical Phlaeothripinae (Fig. 25), but rarely as broad as the stylets of Idolothripinae.

Diagnosis. Head usually longer than wide; postocular setae usually developed; stylet width unusually broad, stylets usually retracted to eyes, close medially; antennae 7-segmented, segments VII and VIII more or less fused, III with 3 sensoria, IV with 4; pronotum usually with 5 pairs of major setae, notopleural sutures usually complete; basantra absent; mesopraesternum transverse; sternopleural sutures present; fore tarsal tooth present in both sexes; fore wings parallel-sided, with duplicated cilia; pelta bell-shaped or triangular; tergites II-VII with wing-retaining setae variable; tube variable in shape, anal setae usually shorter than tube; male sternites IV-VII usually with transverse reticulated areas.

\section{Hoplandrothrips Hood}

About 110 species worldwide are listed in this genus, with four recorded from Australia (Fig. 48), H. flavipes, $H$. fuscus, $H$. quadriconus and $H$. xanthocnemis, but several new species will be published in a manuscript due to go to press this year. These thrips live on dead branches, the adults are usually fully winged, there is considerable sexual dimorphism in some species, and males of some species vary greatly in size and armature that suggest some form of male/male competitive behaviour.

Diagnosis. Often sexually dimorphic, with males varying in body size; head shape variable, usually longer than wide, constricted behind eyes, reticulate dorsally; postocular setae usually well developed, wide apart; stylets usually retracted to eyes and close together medially, rarely short and wider apart; mouth cone variable; antennae 8segmented, III with 2-4 (usually 3) sensoria, IV with 4; pronotum usually with 5 pairs of major setae, major males with anteroangular pair unusually long; notopleural sutures complete; basantra absent; mesopraesternum transverse, or divided into three plates; sternopleural sutures present; fore tarsal tooth present in both sexes, male fore femur often with pair of apical tubercles; fore wings usually weakly constricted medially, with duplicated cilia; pelta bell-shaped; tergites II-VII each with 2 pairs of wing-retaining setae; tube shorter than head, anal setae usually as long as tube or longer; male sternite VIII with or without pore plate. 


\section{Hoplothrips Amyot \& Serville}

With 130 species listed worldwide, this genus poses considerable taxonomic problems and is likely to be polyphyletic. Many species are highly polymorphic, with winged and wingless individuals differing considerably in structure, and also exhibiting sexual dimorphism (Fig. 23). These thrips live on dead wood, and a few species seem to have become widely distributed around the world (Mound \& Walker 1986). Four species are recorded from Australia, H. connexus, H. fungosus, H. melanurus and H. orientalis, but further species are represented in ANIC, mostly from very few specimens, and the genus requires considerable study. As indicated above, this genus is not clearly distinguished from Hoplandrothrips, although Priesner (1961) placed them in different major groups.

Diagnosis. Often sexually dimorphic, also wing-length polymorphic; head usually slightly longer than wide; postocular setae usually well developed, pointed or capitate; stylets usually long and close medially; antennae 8segmented, VIII usually constricted basally, III with 3 sensoria, IV with 4; pronotum with major setae variable; notopleural sutures usually complete, sometimes incomplete or nearly complete; basantra absent, rarely present; mesopraesternum variable, often divided into three plates; sternopleural sutures present; fore tarsal tooth usually present in both sexes; fore wings, parallel-sided if present, with duplicated cilia; pelta usually bell-shaped; tergites II-VII usually each with 2 pairs of wing retaining setae; tube variable in shape, anal setae usually shorter than tube, often longer; male sternites often with paired reticulated areas, sternite VIII with pore plate.

\section{Horistothrips Morgan}

Two species from Australia are placed in this genus, together with three non-Australian species whose generic relationships remain in doubt. The type species, H. australiae (Fig. 24), lives under the bark of certain Eucalyptus trees in eastern Australia (Tree \& Walter 2012), but H. platygaster is known only from a few specimens taken in the north of this continent (Mound 2008).

Diagnosis. Usually micropterous; head longer than wide, posterior half reticulate; postocular setae capitate; stylets retracted to eyes, close together medially; antennae 8-segmented, VIII broad at base, III with 1 sensorium, IV with 2 or 3 sensoria; pronotum with 5 pairs of capitate setae; notopleural sutures complete; basantra absent; mesopraesternum reduced to two lateral triangles; sternopleural sutures long; both sexes with fore tarsal tooth; pelta triangular; tergites II-VII each with 2 pairs of wing retaining setae; tube shorter than head, anal setae much longer than tube; male sternite VIII with large pore plate.

\section{Jacotia Faure}

Of the five described species in this genus, one is from South Africa but the other four are from Australia, $J$. glyptus, J. idaeus, J. palmerae and J. rhodorchus. The genus is widespread across Australia, and several further undescribed species are represented in ANIC (Fig. 26), and these wingless thrips are usual taken at the base of grasses or tussocks of Lomandra.

Diagnosis. Apterous, body with complex reticulate sculpture; head longer than wide; eyes usually prolonged dorsally; postocular setae short and stout; stylets usually long, close together medially; antennae 8-segmented, III with no sensorium or 1 small one, IV with 2 sensoria; pronotum with at least one pair major setae; notopleural sutures usually incomplete; basantra present; mesopraesternum weak, transverse or divided; sternopleural sutures present or weak; fore tarsi without tooth; pelta broad; tergites II-VII without wing retaining setae; tube shorter than head, anal setae shorter than tube; male sternite VIII without pore plate.

\section{Macrophthalmothrips Karny}

There are 16 species recognised in this genus from various tropical countries, and Mound (1972b) provided a key to the 13 species that were then available (Fig. 27). These thrips live on dead branches, and two are known from the tropical north of Australia, M. argus and M. flavafemora.

Diagnosis. Body black with yellow and white markings, eyes bright red; head longer than wide; eyes holoptic, 
surrounding ocellar region; postocular setae usually minute; mouth-cone extending to mesosternum, stylets retracted to eyes, close together medially; antennae 8-segmented, III with 2 sensoria, IV with 4; pronotum with 5 pairs major setae, notopleural sutures incomplete; basantra absent; mesopraesternum divided into two plates; sternopleural sutures present, but short; fore tarsi without tooth; fore wings parallel-sided, with duplicated cilia; pelta bell-shaped; tergites II-VII each with 2 pairs of wing retaining setae; tube shorter than head, anal setae shorter than tube; male sternite VIII without pore plate.
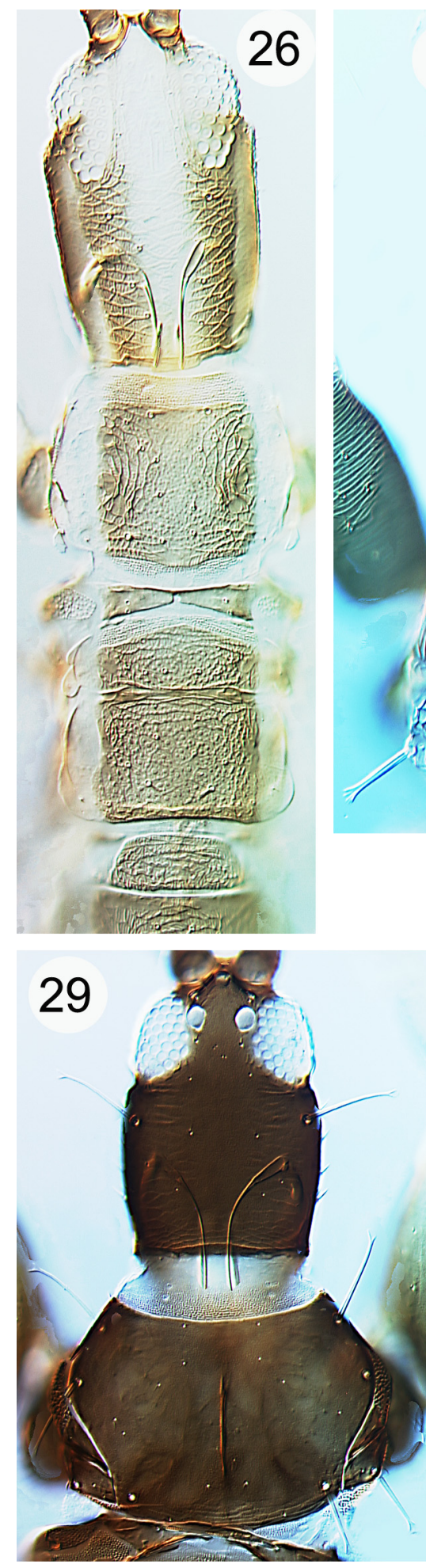
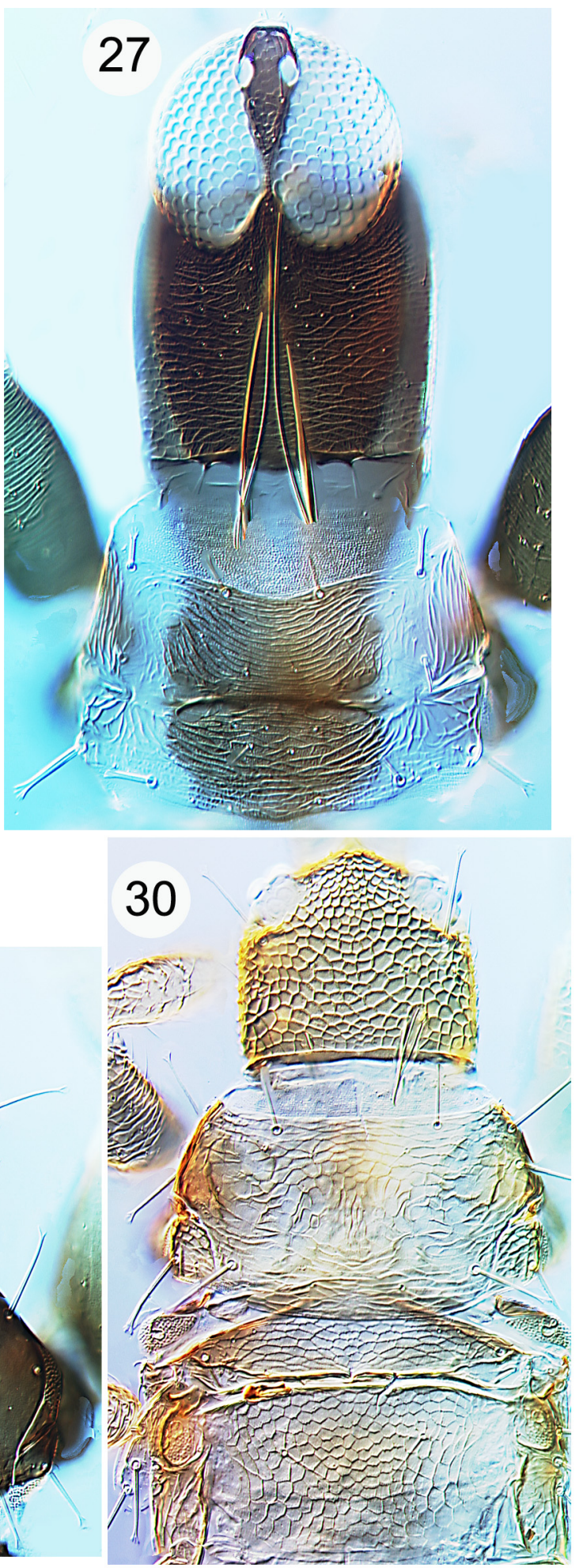
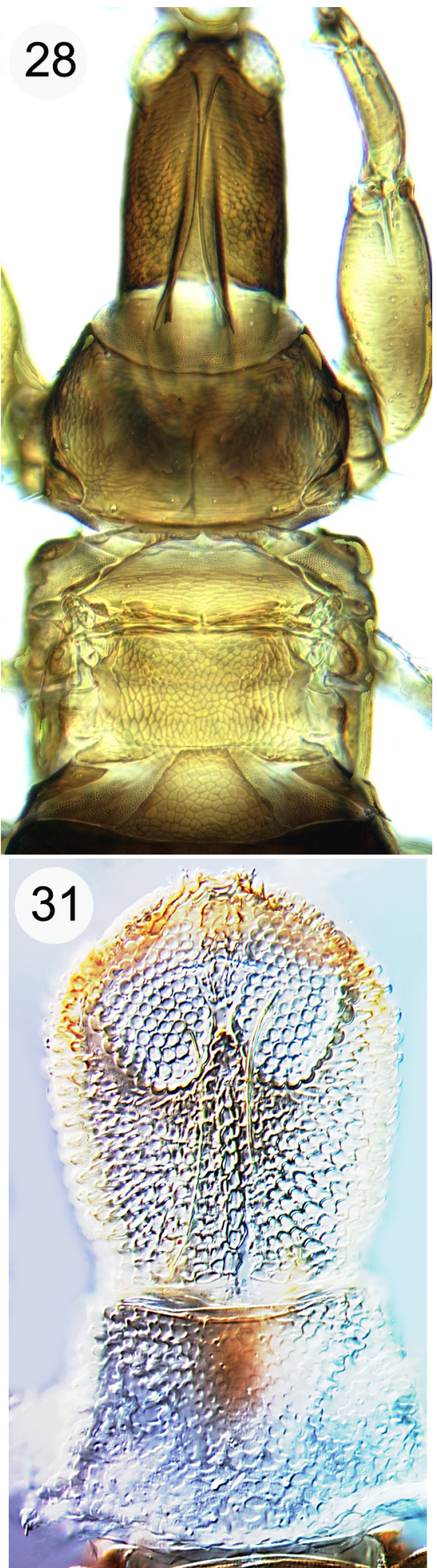

FIGURES 26-31. Phlaeothripinae genera. (26) Jacotia glyptus; (27) Macrophthalmothrips argus; (28) Majerthrips barrowi; (29) Malacothrips sp.; (30) Mystrothrips sp.; (31) Octurothrips pulcher. 


\section{Majerthrips Mound \& Minaei}

Only one species is known in this genus, $M$. barrowi, described from Barrow Island in Western Australia (Mound \& Minaei 2006). This taxon (Fig. 28) was described as related to Holothrips in the Docessissophothripini, because the maxillary stylets are broader than in typical Phlaeothripinae, but the most closely related genus is probably Asemothrips.

Diagnosis. Body strongly reticulate; head about twice as long as wide, elevated in mid-line, postocular setae capitate; stylets retracted to eyes, close together medially; antennae 8-segmented, III with one sensorium, IV with 3 sensoria, VII broadly joined to VIII; pronotum with 4 pairs of capitate setae, anteromarginals reduced; notopleural sutures complete; basantra absent; mesopraesternum complete but eroded or separated into 3 parts; sternopleural sutures long; fore tarsal tooth present in both sexes; wings variable, absent, short or long; pelta variable from Dshaped to narrowly bell-shaped; tergites II-VI usually each with 2 pairs of wing-retaining setae, also one pair of capitate posteromarginal setae; tergite IX postermaginal setae capitate in both sexes; tube much shorter than head; sternites III-VI with worm-like reticulated areas anterolaterally in both sexes.

\section{Malacothrips Hinds}

Worldwide there are 15 species listed in this genus, but these are possibly not all closely related. Five of them are from Africa, but even the nine New World species in the key provided by Mound and Marullo (1996), are curiously diverse. No species of Malacothrips has yet been recorded from Australia, but two specimens in ANIC, from the Northern Territory near Darwin, appear to represent this genus (Fig. 29).

Diagnosis. Head longer than wide, cheeks with weak setae; postocular setae long, capitate; stylets usually about one fifth of head width apart; antennae 8-segmented, VIII with basal neck, III with 3 sensoria, IV with 4; pronotum usually with 4 pairs of slender, capitate setae, anteromarginals reduced; notopleural sutures complete; basantra present; mesopraesternum variable; sternopleural sutures present; fore tarsi usually with tooth in both sexes; fore wings weakly constricted medially, with or without duplicated cilia; pelta bell-shaped; tergites II-VII each with 2 pairs of wing retaining setae; tube shorter than head, anal setae longer than tube; male sternite VIII with or without pore plate.

\section{Mystrothrips Priesner}

Seven species are listed in this genus, one from Brazil but the rest from southeast Asia. In Australia, two undescribed species that are considered to be members of this genus have been studied from leaf litter near Brisbane. Tree \& Walter (2012: 2903) referred to these as "Gen.n. Phlaeo F and G", and a few similar specimens have been studied from sites between northern Queensland and Canberra (Fig. 30). These two species have the prosternal basantra very weak or apparently absent, but are otherwise similar in appearance to species described by Okajima (2006) from southern Japan.

Diagnosis. Head usually as long as wide, weakly to strongly prolonged in front of eyes, strongly reticulate dorsally; cheeks incut behind eyes; postocular setae usually well developed; stylets usually wide apart, V-shaped; antennae 8-segmented, VIII constricted basally, III with 2 or 3 sensoria, IV usually with 3; pronotum usually with 5 pairs of capitate setae, notopleural sutures complete or nearly complete; basantra usually present; mesopraesternum strongly eroded; sternopleural sutures present or absent; fore tarsal tooth usually present, sometimes absent in female; fore wings, if developed, without duplicated cilia; pelta variable; tergites without wing retaining setae; tube shorter than head, anal setae shorter than tube or a little longer; male sternite VIII without pore plate.

\section{Octurothrips Priesner}

The only species in this genus, $O$. pulcher, is known only from Australia, where it is widespread in leaf litter of the dry country west of the Great Divide between South Australia and central Queensland. It shares a very elongate tenth abdominal segment (Fig. 32) with taxa such as Baenothrips and Stephanothrips, but the pelta is different in structure. 
Diagnosis. Body tuberculate-reticulate; head with cheeks rounded, converging to base; eyes large dorsally but not present ventrally; maxillary stylets retracted to eyes, scarcely $1 / 3$ of head width apart; antennae 8-segmented but VI-VIII closely joined, III with no sensoria, IV with 2 sensoria; pronotum with only epimeral setae welldeveloped, no notopleural sutures; basantra large; mesopraesternum complete, slender; no sternopleural sutures; fore tarsi without tooth; fore wings, if present, narrow, no duplicated cilia; pelta broad; abdominal tergites II-VII each with two pairs of broad wing-retaining setae in macropterae; tergite IX at least twice as long as VIII; tube slightly longer than head, anal setae more than twice as long as tube; male sternite VIII without pore plate.
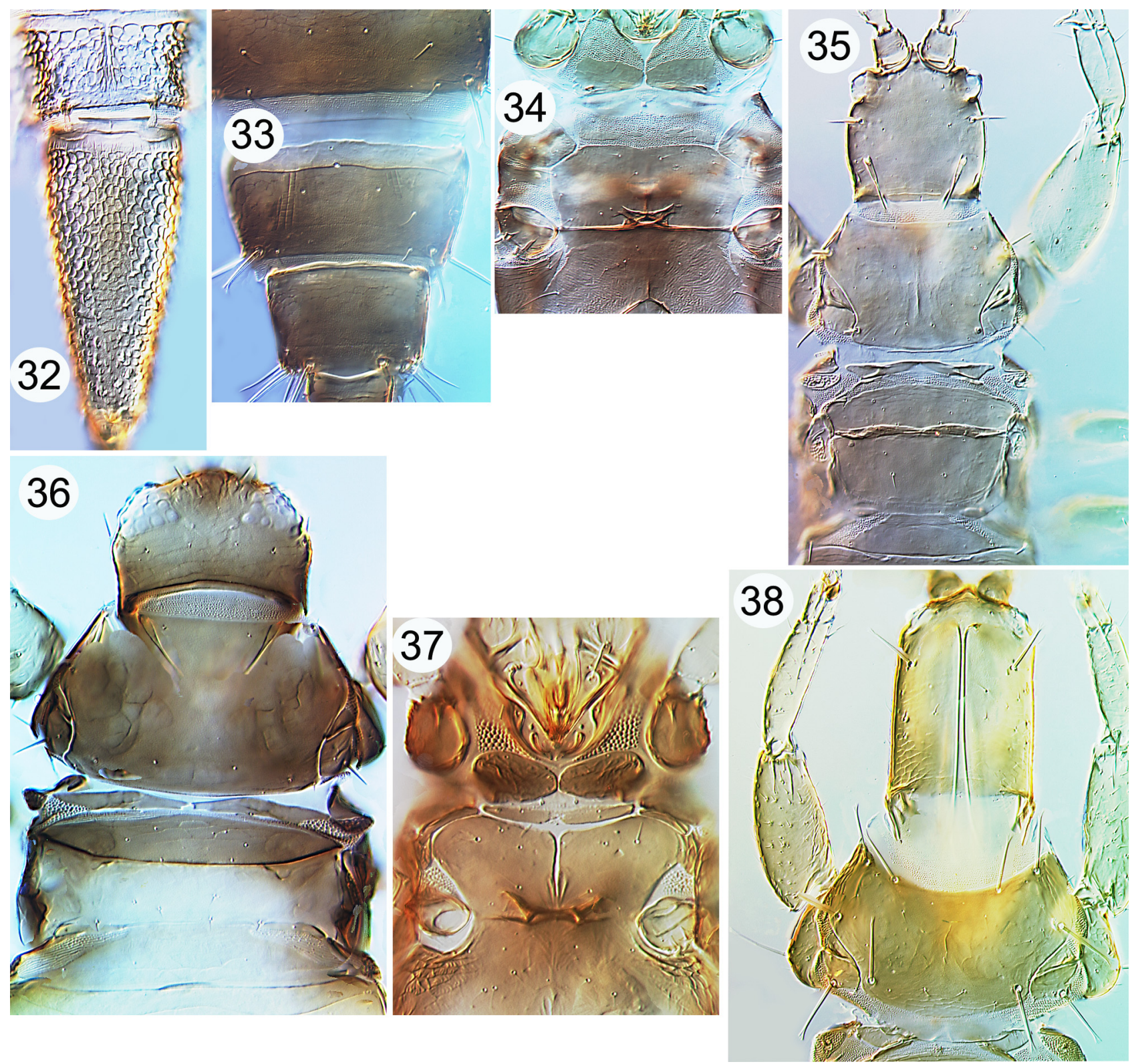

FIGURES 32-38. Phlaeothripinae genera. (32) Octurothrips pulcher, tergites IX-X; (33) Solomonthrips australiensis, tergites VII-IX; (34) Psalidothrips taylori, thoracic sternites-arrows indicate sterno-pleural sutures; (35) Psalidothrips sp., male; (36) Sophiothrips sp.; (37) Senithrips psomus, macroptera thoracic sternites; (38) Pygmaeothrips angusticeps, female microptera.

\section{Plectrothrips Hood}

There are 32 species listed in this genus from various tropical countries, and a key to 29 of these was provided by Okajima (1981). The species live on dead twigs and branches. Members of this genus exhibit an interesting autapomorphy in that the sensorium on the second antennal segment is situated on the basal half of that segment not near the apex (Fig. 11). One species, P. australis, has been collected between Sydney and Brisbane (Fig. 42). 
Diagnosis. Head usually a little longer than wide; postocular setae usually developed, wide apart; stylets variable, usually retracted into head; antennae 8-segmented, II with campaniform sensilla in basal half of segment, VIII long, III with 2 or 3 sensoria, IV with 3; pronotum clearly smaller than prothorax, without major setae; notopleural sutures complete; basantra absent; mesopraesternum reduced; sternopleural sutures present or absent; fore tarsal tooth present in both sexes; fore wings, if developed, parallel-sided, with duplicated cilia; pelta broad with slender lateral lobes; tergite II eroded laterally; tergites II-VII each with one pair of wing retaining setae; tube and anal setae variable; male sternite VIII without pore plate.

\section{Preeriella Hood}

The 20 species listed in this genus come from various tropical countries (Fig. 12). No species are recorded from Australia, but in ANIC there are unidentified specimens from various rainforest sites in Queensland. These are minute insects that are laterally flattened, not dorso-ventrally flattened as in most Thysanoptera. Although commonly associated with dead branches and leaf-litter, these thrips might be predatory on other small arthropods, because one species has been found commonly on the leaves of Lantana in southern Queensland in association with mites. Specimens that probably represent the related genus, Hyidiothrips, have also been seen from Queensland, but members of that genus have antennal segment III completely fused to segment IV (Okajima 2006).

Diagnosis. Minute, usually apterous species; head longer than wide, elevated in mid-line, prolonged in front of eyes; postocular setae usually well developed and expanded at apex; stylets usually subparallel; antennae 8segmented, II with campaniform sensilla at the middle, III short and broad, closely joined to IV, with no sensoria; IV large, with 2 sensoria; pronotum usually with 4 major setae, midlaterals sometimes reduced, notopleural sutures incomplete; basantra weakly present; mesopraesternum reduced; no sternopleural sutures; fore tarsal tooth absent; fore wings, if developed, without duplicated cilia; pelta divided into several plates; tergites III-VII each with one pair of wing retaining setae in macroptera; tube shorter than head, anal setae usually much longer than tube; male sternite VIII without pore plate.

\section{Priesneria Bagnall}

This Australian genus of three Haplothripini species, P. kellyana, P. longistylosa and P. peronis, was reviewed by Mound \& Minaei (2007). The two most common species are found on dead branches, and since they usually occur in low numbers they are possibly predatory rather than fungus-feeding.

Diagnosis. Small, usually apterous species; head usually longer than width; postocular setae usually developed; stylets subparallel medially, variable in length; antennae 8-segmented, III with ring-like swelling near base, VIII usually broad basally, III with 0-2 sensoria, IV with 2-4; pronotum with 4 or 5 major setae, anteromarginals sometimes reduced; notopleural sutures complete; basantra developed; mesopraesternum transverse or eroded medially and divided into two lateral triangles; sternopleural sutures present or absent; fore tarsal tooth usually absent, sometimes with small tooth; fore wings, if developed, constricted medially, with duplicated cilia; pelta D-shaped, or trapezoidal; tergites II-VII each with 2 pairs of wing retaining setae in macroptera; tube shorter than head, anal setae about twice as long as tube; male sternite VIII without pore plate.

\section{Psalidothrips Priesner}

Of the 28 species listed in this genus, only P. taylori is recorded from Australia. However, various undescribed species of Psalidothrips are common in leaf-litter across Australia, and these are represented in ANIC (Figs 34, 35). Okajima (1983) provided a review of the genus with a key to the 17 species then known from around the world. These thrips are particularly flattened dorso-ventrally, but otherwise the genus seems likely to be related to Hoplandrothrips. 
Diagnosis. Body commonly strongly flattened, dorso-ventrally; head usually a little longer than width; postocular setae developed, wide apart, situated near cheeks, cheeks usually incut just behind eyes; stylets usually short, V- or U-shaped; antennae 8-segmented, VIII usually constricted basally, III with 2 or 3 sensoria, IV with 24; pronotum usually with 3 major setae, anteromarginal and anteroangular setae reduced; notopleural sutures complete; basantra absent; mesopraesternum transverse; sternopleural sutures present; fore tarsal tooth present in male, usually absent in female; fore wings, if developed, weakly constricted medially, without duplicated cilia, subbasal setae minute; pelta hat- or bell-shaped; tergites II-VII each with 2 pairs of wing retaining setae in macroptera; tube shorter than head, anal setae about as long as tube; male sternite VIII with pore plate.

\section{Pygmaeothrips Karny}

The only species in this genus, P. angusticeps, has been found widely in tropical countries, and as a result of the polymorphism it exhibits it has been described under several different names. A few specimens have been seen from dead wood at several sites across northern Australia (Fig. 38).

Diagnosis. Head longer than wide, postocular setae long, capitate; mouth-cone extending to ferna; stylets retracted to eyes, close together medially; antennae 8-segmented, III and IV each with 3 stout sensoria; pronotum with 5 slender capitate setae; notopleural sutures complete; basantra absent; mesopraesternum eroded medially, or separated into 2 lateral triangles; no sternopleural sutures; fore tarsal tooth absent; fore wings, if present, weakly constricted medially, with duplicated cilia; pelta D-shaped; tergites II-VI each with 2 pairs of wing retaining setae in macroptera, tergite IX postermaginal setae usually longer than tube; tube shorter than head, anal setae about as long as tube; male sternite VIII without pore plate.

\section{Senithrips Mound \& Minaei}

The single minute, usually wingless, species in this genus, S. psomus, is known only from Barrow Island, Western Australia (Mound \& Minaei 2006). As in other small wingless thrips, many structural features are severely reduced, with resultant problems in suggesting any relationships (Figs 20, 37).

Diagnosis. Head longer than wide, without major setae; eyes reduced to 6 ommatidia in aptera and macroptera; mouth-cone short and rounded, stylets long, retracted to eyes, close together medially; antennae 6-segmented, morphological segments VI-VIII fused, III with no sensorium, IV with 2 sensoria; pronotal setae minute, notopleural sutures incomplete; basantra absent; mesopraesternum eroded into 2 lateral plates, mesoeusternum divided longitudinally; no sternopleural sutures; fore tarsal tooth absent; fore wing when present swollen at base, parallel-sided, without duplicated cilia; pelta broad but slender; tergites III-VII of macropterae each with 2 pairs of sigmoid wing retaining setae, with transverse row of more than 12 small setae; tergite IX postermaginal setae shorter than tube; tube shorter than head, anal setae much shorter than tube; male sternite VIII without pore plate.

\section{Solomonthrips Mound}

Of the eight species in this genus, five were described from leaf-litter in the Solomon Islands, one from Borneo, and two from northern Queensland, S. australiensis and S. brooksi. The presence of wing-retaining setae on the eighth abdominal tergite is unique to the members of this genus (Fig. 33).

Diagnosis. Body usually reticulate in part; head about as long as wide, cheeks slightly incut behind eyes; posterocular setae capitate, wide apart; mouth-cone short and rounded, stylets wide apart, retracted half-way into head; antennae 8-segmented, VIII scarcely narrowed basally, III and IV each with 2 sensoria; pronotum with 3 or 4 capitate setae, anteroangulars absent; notopleural sutures complete; basantra absent; mesopresternum reduced; no sternopleural sutures; fore tarsal tooth present in both sexes; usually micropterous; pelta hat-shaped; tergites II-VII with 1 or 2 pairs of wing retaining setae, VIII with 2 pairs of small wing retaining setae; tube shorter than head, anal setae much shorter than tube; male sternite VIII without pore plate. 


\section{Sophiothrips Hood}

The members of this genus are amongst the smallest of Phlaeothripinae. However, they exhibit remarkable polymorphism, such that the different morphs sometimes cannot be recognised as conspecific without field data (Mound 1977b). Males vary greatly in size within some species, and large males may bear a prominent tubercle ventrally on the head, or dorsally on tergite IX. Currently 25 species are listed in the genus, from various areas mainly in the tropics but also New Zealand. One species, S. greensladei, is recorded from eastern Australia, but in ANIC there are many unidentified specimens from various localities across this continent (Fig. 36).

Diagnosis. Head broader than long; interocellar and postocular setae present but small, postoculars near cheeks; mouth-cone rounded, stylets short, V-shaped, restricted to mouth-cone; antennae 8-segmented, VIII not constricted basally, III with 1 or 2 sensoria, IV with 2; pronotum usually with 3 pairs of major setae; notopleural sutures usually complete; basantra small or absent; mesopraesternum narrow or reduced; sternopleural sutures present; fore tarsal tooth present in male, present or absent in female; fore wings, if present, parallel-sided without duplicated cilia; pelta broad; tergites II-VII with one pair of wing retaining setae; tube longer than head, anal setae much shorter than tube; male sternite VIII usually without pore plate.

\section{Stephanothrips Trybom}

No identification keys exist to the 29 described species of this genus (Fig. 40). These have been described from many parts of the tropics and subtropics, living either in leaf-litter or on dead twigs. Three species are recorded from Australia (Mound 1972a), of which S. barretti and S. ferrari are endemics, but S. occidentalis is found worldwide. At least one further undescribed species is represented in ANIC.

Diagnosis. Body tuberculate-reticulate, usually wingless; head longer than wide, with 1-3 pairs of prominent setae on anterior margin; postocular setae reduced; mouth-cone short and rounded, stylets retracted to eyes, close together medially; antennae 5- or 6-segmented, morphological segments III-V fused, sometimes also VII and VIII; pronotum with only epimeral setae developed; notopleural sutures reduced; basantra present; mesopraesternum reduced; no sternopleural sutures; fore tarsal tooth absent; abdominal tergite I transverse and closely joined to II; tergites without wing retaining setae; tergite IX longer than broad; tube long and slender, longer than head, anal setae long, about twice as long as tube; male sternite VIII without pore plate.

\section{Stomothrips Okajima}

Known only from northern Australia, this genus comprises two species, S. cycasi and S. mouldeni, both of which were collected from the fronds of Cycas species that apparently were affected by fungus. These two thrips both have the mouth-cone very long, but in cycasi this is directed posteriorly, whereas in mouldeni it is directed downwards and thus appears shorter in dorsal view (Figs 39, 43).

Diagnosis. Head much longer than wide; postocular setae long, capitate; mouth-cone long, stylets retracted to eyes, close together medially; antennae 8-segmented, III with 1 sensorium, IV with 2 sensoria; pronotum with 5 pairs of capitate setae; notopleural sutures complete; basantra present; mesopraesternum transverse, slender or divided; no sternopleural sutures; fore tarsi without tooth; wings weakly constricted medially, without duplicated cilia; pelta hat-shaped; tergites II-VII each with 2 pairs of wing retaining setae; tube much shorter than head, anal setae about as long as tube; male sternite VIII without pore plate.

\section{Strepterothrips Hood}

The nine species in this genus are found in various parts of the tropics and subtropics, usually living on dead twigs (Fig. 41). Three species, S. apterus, S. orientalis and S. tuberculatus, are known from Australia, but at least one further undescribed species is represented in ANIC.

Diagnosis. Body strongly reticulate; head with eyes large dorsally, but with few ommatidia ventrally; postocular setae short, capitate; maxillary stylets retracted to eyes, close together medially; antennae 7-segmented, 
IV-VII with narrow pedicels; III with one sensorium, IV with 2 sensoria; pronotal major setae short, broadly expanded; basantra reduced or absent; mesopraesternum reduced to 2 small triangular lateral sclerites; sternopleural sutures short; fore tarsi without tooth in both sexes but fore tarsal hamus large in males; fore tibia in males with small apical tubercle; fore wings, when present, constricted medially, no duplicated cilia; pelta broad in apterae, hat-shaped in macropterae; tergites II-VII each with 2 pairs of broad wing-retaining setae in macropterae; S1 setae on tergite IX broadly expanded, S2 pointed; male without sternal pore plates.

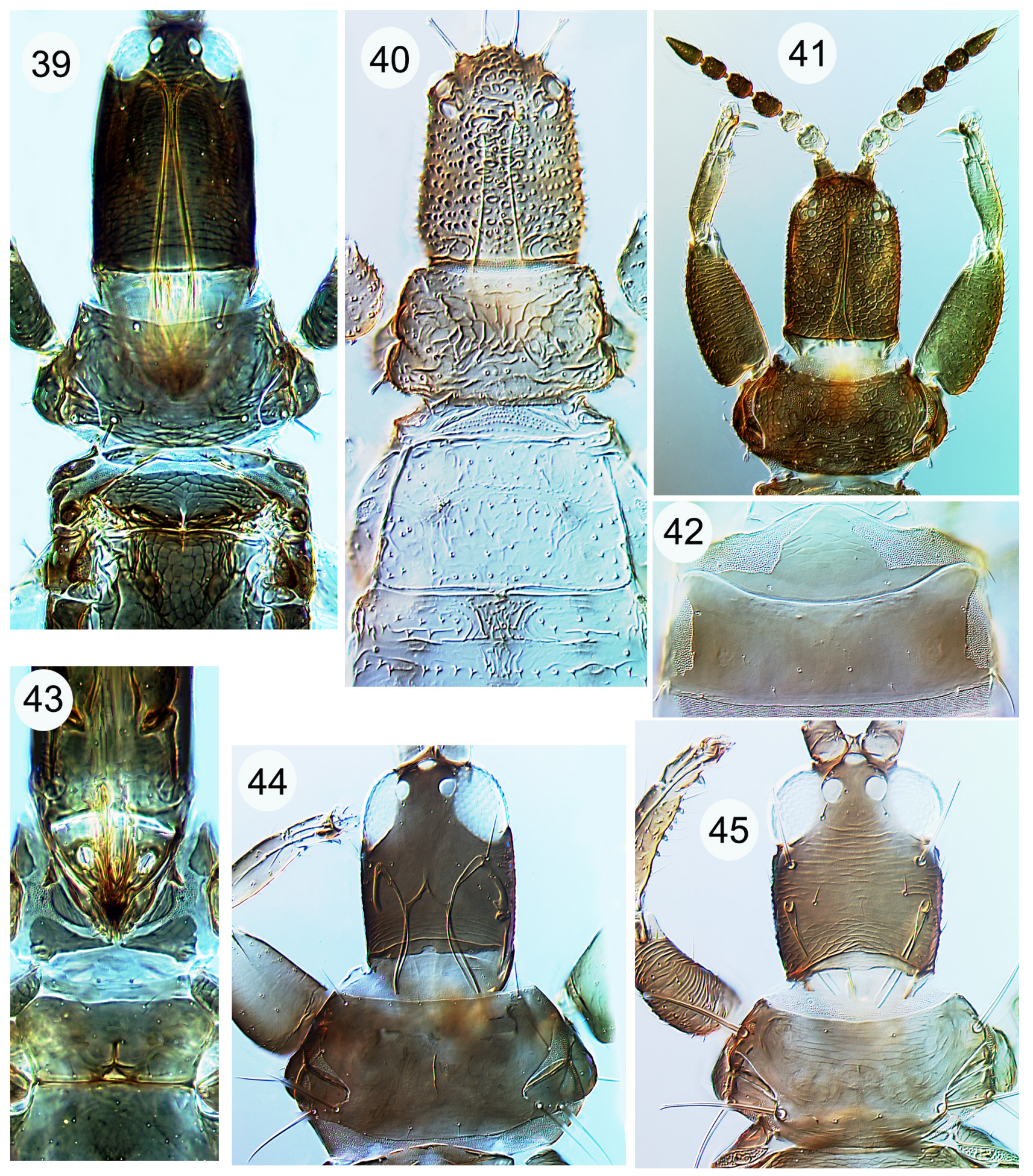

FIGURES 39-45. Phlaeothripinae genera. (39) Stomothrips mouldeni; (40) Stephanothrips occidentalis; (41) Strepterothrips orientalis, male; (42) Plectrothrips australis, pelta \& tergite II; (43) Stomothrips mouldeni, thoracic sternites; (44) Yarnkothrips kolourus; (45) Terthrothrips ananthakrishnani. 


\section{Streptothrips Priesner}

Okajima (1981) provided a revision and key to five of the 10 species now recognised in this genus of Plectrothripini. These are all from tropical countries, eight from the Old World of which S. tribulatius is from Queensland. Winged and wingless individuals of species in this genus differ greatly in structure.

Diagnosis. Head much longer than wide; postocellar and postocular setae long and bluntly pointed; mouthcone short and rounded, stylets deeply retracted into head, close together medially; antennae 8-segmented, VIII long, slightly constricted basally, III and IV broad, each with 4-12 short stout sensoria; pronotum reduced to a shield, with 2 pairs of epimeral setae; notopleural sutures complete; basantra weak; mesopraesternum reduced or absent; no sternopleural sutures; fore tarsal tooth stout in both sexes, mid- and hind tibiae with apical spur-like stout setae; fore wings, if present, with duplicated cilia; pelta broad, posterior margin eroded, sometimes into three plates; tergites without wing retaining setae; tube shorter than head, anal setae about $1.5 \mathrm{X}$ as long as apical width of tube; sternite VIII with a series of long, stout posteromarginal setae; male sternite VIII without pore plate.

\section{Terthrothrips Karny}

Of the 25 species listed in this genus, 22 are from the Neotropics (Mound 1977a) and three from southern Japan, all living in leaf-litter. Terthrothrips ananthakrishnani Kudo, described from Nepal (Kudo 1978) and recorded from southern Japan (Okajima 2006), is here recorded from Australia (Fig. 45). Four females and one male (all macropterae) of this species have been identified from Australia, based on the descriptions of Kudo and Okajima, collected at Kuranda, Queensland, on dead leaves, 4.xi.2008. Two specimens in ANIC taken near Darwin have the head strongly reticulate, and possibly also represent either this genus or Eurythrips, a closely related genus (Mound 1977a).

Diagnosis. Head usually longer than wide, slightly prolonged in front of eyes, cheeks incut behind eyes; postocular setae long, capitate; mouth-cone short and rounded, stylets short, V-shaped; antennae 8-segmented, VIII constricted basally, III and IV each with 2 or 3 sensoria; pronotum with 3 or 4 slender, capitate setae, anteromarginals reduced; notopleural sutures complete or nearly complete; basantra usually present; mesopraesternum transverse; no sternopleural sutures; fore tarsal tooth present in both sexes; fore wings, if present, parallel-sided without duplicated cilia; pelta variable; tergites II-VII each with 2 pairs of wing retaining setae; tube shorter than head, anal setae much shorter than tube, about twice as long as apical width of tube; male sternite VIII without pore plate.

\section{Tylothrips Hood}

All but one of the 23 species listed in this genus are from the Neotropics (Mound 1977a), the exception being from India. One specimen of this genus was collected from Eucalyptus bark near Canberra (Fig. 46), and another specimen near Brisbane. Species of this genus are similar in general appearance to those of Terthrothrips, and similarly are typical leaf-litter thrips.

Diagnosis. Head longer than wide; postocular setae long, capitate; mouth-cone short and rounded, stylets wide apart, retracted half way into head; antennae 8-segmented, III and IV usually each with 4 sensoria; pronotum with 4 long, capitate setae, anteromarginals reduced; notopleural sutures complete; basantra present; meso- and metathorax with pair of long capitate setae ventrolaterally; mesopraesternum transverse; no sternopleural sutures; fore tarsal tooth present in both sexes; fore wings parallel-sided, without duplicated cilia; pelta triangular; tergites II-VII each with 2 pairs of wing retaining setae; tube slightly shorter than head, anal setae much shorter than tube; male sternite VIII without pore plate.

\section{Yarnkothrips Mound \& Walker}

Described from New Zealand (Mound \& Walker 1986), the only described species, Y. kolourus, has recently been found at several sites in Australia near Canberra, in southern New South Wales and Tasmania (Fig. 44). Moreover, specimens representing at least one more species of this genus are available in ANIC. 

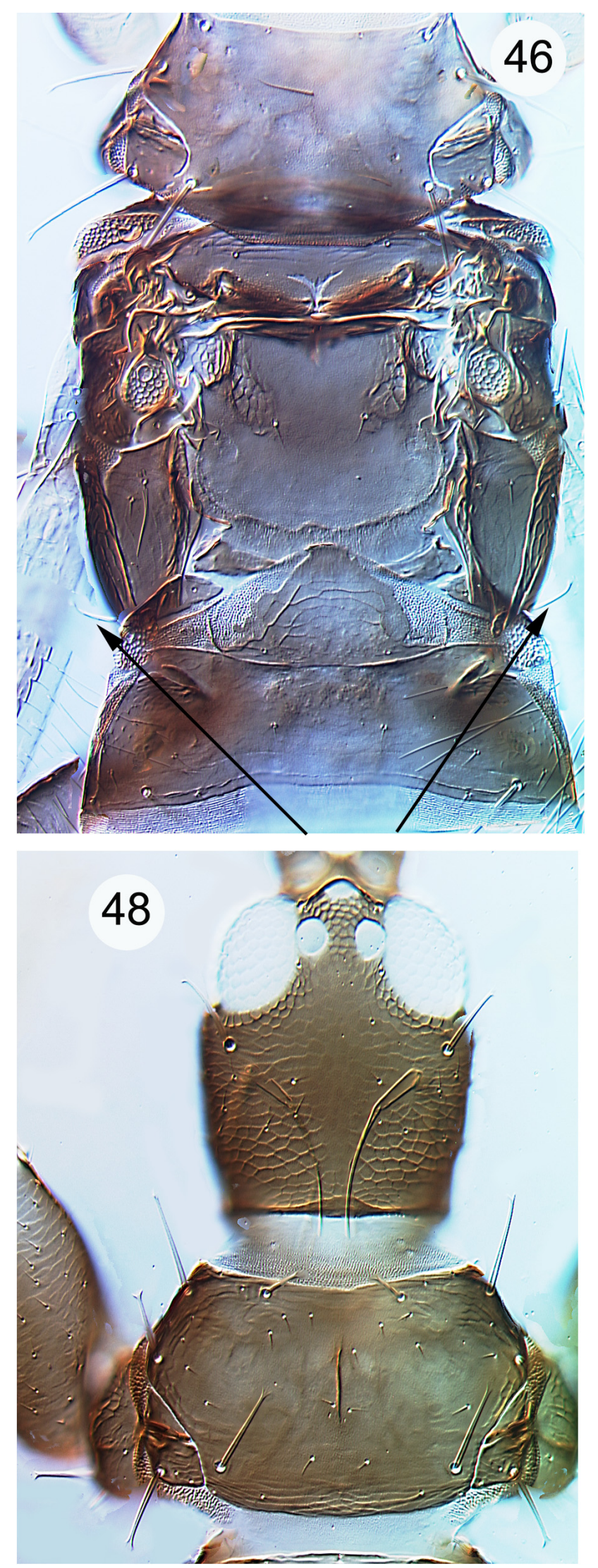
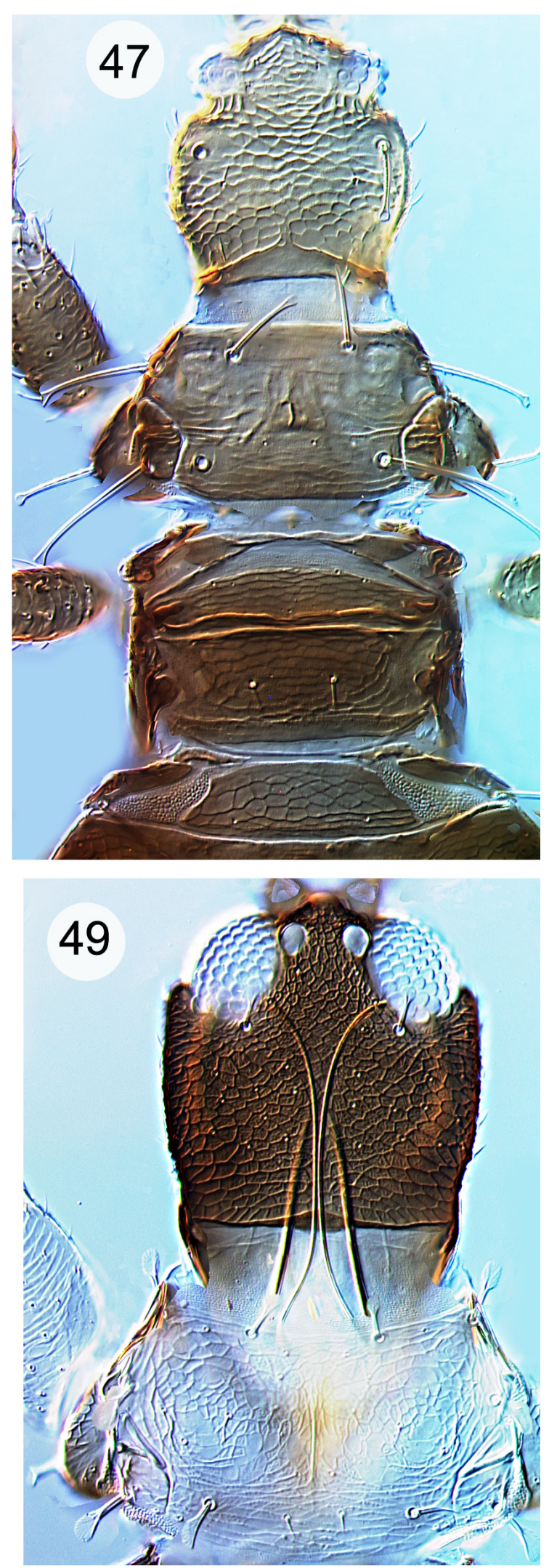

FIGURES 46-49. Phlaeothripinae genera. (46) Tylothrips sp.-arrows indicate metathoracic ventro-lateral setae; (47) Zemiathrips trisetis; (48) Hoplandrothrips flavipes, male; (49) Azaleothrips lepidus. 
Diagnosis. Head longer than wide; postocular setae shorter than eye length; stylets retracted almost to eyes, maxillary bridge arched; antennae 8-segmented, III with 3 sensoria, IV with 4; pronotum with 4 pairs of long pointed setae; notopleural sutures incomplete; basantra present; mesopraesternum transverse, fused to mesoeusternum; sternopleural sutures present and wide; fore tarsal tooth small; fore wings parallel-sided, with duplicated cilia; pelta elongate; tergites II-VII each with one pair of wing retaining setae; tube shorter than head, anal setae short, less than half as long as tube; male sternite VIII with transverse pore plate.

\section{Zemiathrips Mound}

This genus is known only from Australia, where it is widespread in Eucalyptus leaf-litter (Fig. 47). The five known species, Z. anatolis, Z. biseta, Z. greensladeae, Z. triseta and Z. uptoni, have been found widely across eastern Australia, from Tasmania to Queensland.

Diagnosis. Head about as long as wide, usually reticulate, cheeks swollen and incut behind eyes; postocular setae long, capitate; mouth-cone short, stylets wide apart; antennae 8-segmented, I-III usually with dorsal setae capitate, VIII constricted basally, III and IV each with 2 sensoria; pronotum with 4 pairs of long, capitate setae, anteroangulars reduced; notopleural sutures complete or incomplete; basantra present; mesopraesternum transverse; no sternopleural sutures; fore tarsi usually without tooth; fore wings, if present, without duplicated cilia; pelta rectangular or anterior margin rounded; tergites II-VII usually each with 2 pairs of wing retaining setae in macroptera, with one pair in aptera; tube shorter than head, anal setae much shorter than tube; male sternite VIII without pore plate.

\section{Acknowledgements}

This paper was produced as part of a programme studying the diversity of Australian fungus-feeding Thysanoptera that was supported in part by a BushBlitz Research Grant from Australian Biological Resources Study, Canberra.

\section{References}

Buckman, R.S., Mound, L.A. \& Whiting, M.F. (2013) Phylogeny of thrips (Insecta: Thysanoptera) based on five molecular loci. Systematic Entomology, 13, 123-133. http://dx.doi.org/10.1111/j.1365-3113.2012.00650.x

Crespi, B.J., Morris, D.C. \& Mound, L.A. (2004) Evolution of ecological and behavioural diversity: Australian Acacia thrips as model organisms. Australian Biological Resources Study \& Australian National Insect Collection, CSIRO, Canberra, Australia, $328 \mathrm{pp}$.

Eow, L.-X., Mound, L.A. \& Ng, Y.-F. (2011) Introduction to Southeast Asian spore-feeding Thysanoptera (Phlaeothripidae, Idolothripinae) Zootaxa, 2928, 1-19.

Goldarazena, A. (2010) Bocathrips okajimai gen. et sp. n.(Thysanoptera, Phlaeothripidae), an Australian fungus-feeding thrips. Australian Journal of Entomology, 49, 121-125. http://dx.doi.org/10.1111/j.1440-6055.2010.00750.x

Han, Y-F. (1997) Economic Insect Fauna of China. 55 Thysanoptera. Editorial Committee of Fauna Sinica, Science Press, Beijing, $514 \mathrm{pp}$.

Kudo, I. (1978) Zwei neue Japanische Arten der Gattung Terthrothrips Karny (Thysanoptera, Phlaeothriidae). Kontyu, 46, 813.

Minaei, K. (2013) The Phlaeothrips-lineage of fungus feeding thrips (Thysanoptera: Phlaeothripidae) in Iran with a new species of Hindsiothrips. Zootaxa, 3599 (3), 279-290. http://dx.doi.org/10.11646/zootaxa.3599.3.5

Mound, L.A. (1970) Convoluted maxillary stylets and the systematics of some Phlaeothripine Thysanoptera from Casuarina trees in Australia. Australian Journal of Zoology, 18, 439-463. http://dx.doi.org/10.1071/zo9700439

Mound, L.A. (1971) The complex of Thysanoptera in rolled leaf galls on Geijera. Journal of the Australian Entomological Society, 10, 83-97.

http://dx.doi.org/10.1111/j.1440-6055.1971.tb00014.x 
Mound, L.A. (1972a) Species complexes and the generic classification of leaf-litter thrips of the Tribe Urothripini (Phlaeothripidae). Australian Journal of Zoology, 20, 83-103. http://dx.doi.org/10.1071/zo9720083

Mound, L.A. (1972b) Tropical fungus-feeding Thysanoptera of the genus Macrophthalmothrips. Journal of Entomology (B), $41,77-88$. http://dx.doi.org/10.1111/j.1365-3113.1972.tb00030.x

Mound, L.A. (1974) Spore-feeding Thrips (Phlaeothripidae) from Leaf Litter and Dead Wood in Australia. Australian Journal of Zoology. Supplement, 27, 1-106. http://dx.doi.org/10.1071/ajzs027

Mound, L.A. (1977a) Species diversity and the systematics of some New World leaf-litter Thysanoptera (Phlaeothripinae; Glyptothripini). Systematic Entomology, 2, 225-244. http://dx.doi.org/10.1111/j.1365-3113.1977.tb00371.x

Mound, L.A. (1977b) Leaf-litter Thysanoptera of the sub-tribe Williamsiellina (Phlaeothripidae). Bulletin of the British Museum (Natural History). Entomology, 36, 171-192.

Mound, L.A. (2005) Fighting, flight and fecundity: behavioural determinants of Thysanoptera structural diversity. In: Ananthakrishnan, T.N. \& Whitman, D. (Eds), Insects and phenotypic plasticity. Science Publishers Inc. Enfield, NH, USA, pp. 81-105

Mound, L.A. (2008) Identification and host associations of some Thysanoptera Phlaeothripinae described from Australia pre1930. Zootaxa, 1714, 41-60.

Mound, L.A. (2011) Order Thysanoptera Haliday, 1836. In: Zhang, Z.-Q. (Ed), Animal biodiversity: An outline of higher-level classification and survey of taxonomic richness. Zootaxa, 3148, pp. 201-202.

Mound, L.A. (2013) Thysanoptera. Australian Faunal Directory. Australian Biological Resources Study, Canberra. Available from: http://www.environment.gov.au/biodiversity/abrs/online-resources/fauna/afd/taxa/Thysanoptera (Accessed 24 May 2013)

Mound, L.A. \& Crespi, B.J. (1992) The complex of phlaeothripine thrips (Insecta, Thysanoptera) in woody stem galls of Casuarina in Australia. Journal of Natural History, 26, 395-406. http://dx.doi.org/10.1080/00222939200770221

Mound, L.A. \& Dang L-H. (in press) Five species of Asian or New Zealand Thysanoptera-Phlaeothripidae newly recorded from Australia. Australian Entomologist.

Mound, L.A. \& Marullo, R. (1996) The Thrips of Central and South America: An Introduction. Memoirs on Entomology, International, 6, 1-488.

Mound, L.A. \& Minaei, K. (2006) New fungus-feeding thrips (Thysanoptera-Phlaeothripinae) from tropical Australia. Zootaxa, 1150, 1-17.

Mound, L.A. \& Minaei, K. (2007) Australian insects of the Haplothrips lineage (Thysanoptera - Phlaeothripinae). Journal of Natural History, 41, 2919-2978. http://dx.doi.org/10.1080/00222930701783219

Mound, L.A. \& Palmer, J.M. (1983) The generic and tribal classification of spore-feeding Thysanoptera (Phlaeothripidae: Idolothripinae). Bulletin of the British Museum (Natural History). Entomology, 46, 1-174.

Mound, L.A., Paris, D. \& Fisher, N. \& Tree, D.C. (2013) World Thysanoptera—an information system. Available from: http:// anic.ento.csiro.au/thrips/ (Accessed 24 May 2013)

Mound, L.A. \& Tree, D.J. (2011) Australian spore-feeding thrips of the genus Bactrothrips (Thysanoptera, Idolothripinae). Zootaxa, 3087, 56-65.

Mound, L.A. \& Walker, A.K. (1986) Tubulifera (Insecta: Thysanoptera). Fauna of New Zealand, 10, 1-140.

Mound, L.A. \& Walker, A.K. (2012) The Australia-New Zealand connection re-visited, with two new species of Cartomothrips (Thysanoptera, Phalaeothripidae). Zootaxa, 3487, 58-64.

Okajima, S. (1979) A revisional study of the genus Apelaunothrips (Thysanoptera, Phlaeothripidae). Systematic Entomology, 4, 39-64. http://dx.doi.org/10.1111/j.1365-3113.1979.tb00610.x

Okajima, S. (1981) A revision of the tribe Plectrothripini of fungus-feeding Thysanoptera (Phlaeothripidae: Phlaeothripinae). Systematic Entomology, 6, 291-336. http://dx.doi.org/10.1111/j.1365-3113.1981.tb00441.x

Okajima, S. (1983) Studies on some Psalidothrips species with key to the world species (Thysanoptera: Phlaeothripidae). Journal of Natural History, 17, 1-13. http://dx.doi.org/10.1080/00222938300770011

Okajima, S. (1987) Studies on the old world species of Holothrips (Thysanoptera, Phlaeothripidae). Bulletin of the British Museum (Natural History), Entomology, 54, 1-74.

Okajima, S. (2006) The Suborder Tubulifera (Thysanoptera). The Insects of Japan, 2, 1-720.

Priesner, H. (1961) Das System der Tubulifera (Thysanoptera). Anzeiger mathematisch-naturwissenschaftliche Klasse, Österreichische Akademie der Wissenschaften (1960), 13, 283-296. 
Priesner, H. (1964) Ordnung Thysanoptera (Fransenflügler, Thripse). In: Franz, H. (Ed), Bestimmungsbücher zur Bodenfauna Europas, 2, 1-242.

http://dx.doi.org/10.1002/mmnd.4810110421

Stannard, L.J. (1957) The phylogeny and classification of the North American genera of the sub-order Tubulifera (Thysanoptera). Illinois Biological Monographs, 25, 1-200.

http://dx.doi.org/10.5962/bhl.title.50287

Stannard, L.J. (1968) The Thrips, or Thysanoptera, of Illinois. Bulletin of the Illinois Natural History Survey, 29, $213-552$.

ThripsWiki (2013) ThripsWiki - providing information on the World's thrips. Available from: http://thrips.info/wiki/ (Accessed 27 May 2013)

Tree, D.J. \& Walter, G.H. (2012) Diversity and abundance of fungivorous thrips (Thysanoptera) associated with leaf-litter and bark across forest types and two tree genera in subtropical Australia. Journal of Natural History, 46, 2897-2918.

http://dx.doi.org/10.1080/00222933.2012.737037 